\title{
High connectivity across the fragmented chemosynthetic ecosystems of the deep Atlantic Equatorial Belt: efficient dispersal mechanisms or questionable endemism?
}

\author{
Sara Teixeira ${ }^{1,2, *}$, Karine Olu ${ }^{1}$, Carole Decker ${ }^{1}$, Regina L. Cunha ${ }^{2}$, Sandra Fuchs ${ }^{1}$, Stéphane Hourdez ${ }^{3}$, \\ Ester A. Serrão ${ }^{2}$, Sophie Arnaud-Haond ${ }^{1}$ \\ ${ }^{1}$ Ifremer, Laboratoire "Environment Profond" (EEP-LEP), Plouzané, France \\ ${ }^{2}$ Centre of Marine Sciences, CIMAR, University of Algarve, Faro, Portugal \\ ${ }^{3}$ Station Biologique de Roscoff, Equipe Ecophysiologie Adaptation et Evolution Moleculaires, Roscoff, France \\ *: Corresponding author : Sara Teixeira, Fax: +351 289800069 ; email address : steixeira@ualg.pt
}

\begin{abstract}
:
Chemosynthetic ecosystems are distributed worldwide in fragmented habitats harbouring seemingly highly specialized communities. Yet, shared taxa have been reported from highly distant chemosynthetic communities. These habitats are distributed in distinct biogeographical regions, one of these being the so-called Atlantic Equatorial Belt (AEB). Here, we combined genetic data (COI) from several taxa to assess the possible existence of cryptic or synonymous species and to detect the possible occurrence of contemporary gene flow among populations of chemosynthetic species located on both sides of the Atlantic. Several Evolutionary Significant Units (ESUs) of Alvinocarididae shrimp and Vesicomyidae bivalves were found to be shared across seeps of the AEB. Some were also common to hydrothermal vent communities of the Mid-Atlantic Ridge (MAR), encompassing taxa morphologically described as distinct species or even genera. The hypothesis of current or very recent large-scale gene flow among seeps and vents was supported by microsatellite analysis of the shrimp species Alvinocaris muricolalAlvinocaris markensis across the AEB and MAR. Two nonmutually exclusive hypotheses may explain these findings. The dispersion of larvae or adults following strong deep-sea currents, possibly combined with biochemical cues influencing the duration of larval development and timing of metamorphosis, may result in large-scale effective migration among distant spots scattered on the oceanic seafloor. Alternatively, these results may arise from the prevailing lack of knowledge on the ocean seabed, apart from emblematic ecosystems (chemosynthetic ecosystems, coral reefs or seamounts), where the widespread classification of endemism associated with many chemosynthetic taxa might hide wider distributions in overlooked parts of the deep sea.
\end{abstract}

Keywords : Atlantic equatorial belt ; chemosynthetic habitats ; deep-sea connectivity ; endemic bivalves ; endemic shrimp ; genetic diversity ; microsatellite markers ; mitochondrial COI gene 


\section{Introduction}

Hydrothermal vents, cold seeps, and other deep-sea sites of organic enrichment (whale- and wood-falls) have in common the use of reduced chemicals as energy source by chemoautotrophic bacteria that function as primary producers, allowing very high biomass production far from the euphotic zone (Desbruyères et al. 2000). Despite sharing chemoautotrophy for primary production of organic matter, chemosynthetic ecosystems differ in many characteristics. Hydrothermal vents, due to their tectonic and volcanic nature, are usually ephemeral and characterized by high temperatures, high sulphide, high heavy metal concentrations, and are generally not strongly sedimented. In comparison, more stable and sediment-rich cold seeps are often associated to cold temperatures and diffusion of methanerich fluids, harbouring more stable communities, which include species with extreme life span (Bergquist et al. 2000). Hydrothermal vents are scattered along mid-ocean ridges and back-arc spreading centres while cold seeps are patchily distributed along active or passive margins associated with accumulated sediment. Despite their habitat differences, the chemosynthetic communities inhabiting these two kinds of ecosystems harbour common genera and sister species, suggesting a shared history of colonization during the evolutionary history of deep ocean habitats (Hecker 1985; McLean 1985).

Cold seeps, because of their distribution along continental margins, have been suggested as potential stepping-stone habitats for long-distance dispersal of vent species (Craddock et al. 1995). However, very few shared species have been detected among those ecosystems (Peek et al. 2000; Baco et al. 1999; Andersen et al. 2004; Jollivet et al. 2000; Turnipseed et al. 2003; Tyler \& Young 1999; Sibuet \& Olu 1998). One exception, supported by genetic analyses, is the vestimentiferan tubeworm Escarpia spicata found across different kinds of chemosynthetic habitats, namely cold seeps, whale falls and sedimented hydrothermal vents 
off the coast of California (Black et al. 1997). In the Northwestern Pacific, several morphologically determined species have been reported to occur in both seeps and vents; genetic connectivity between both ecosystems has been shown for Lamellibrachia tubeworms and Bathymodiolus mussels, but not for Vesicomyidae bivalves (Watanabe et al. 2010). Additionally, Vesicomyidae bivalves from whale carcasses in the Eastern Pacific have been shown to be genetically close to both seep (Phreagena kilmeri) and vent (Archivesica gigas) vesicomyids from the same region (Baco et al. 1999).

Since the discovery of these habitats in the mid 1970's, one of the most puzzling issues has been the influence of past and present connectivity on the nature of species assemblages and their geographic distribution (Corliss et al. 1979). Several studies to date have addressed the biogeography of vent ecosystems (Tunnicliffe 1997; Van Dover et al. 2002; Bachraty et al. 2009). The most recent assessment included 63 hydrothermal vents distributed worldwide, and revealed the existence of five major biogeographic provinces: Mid-Atlantic Ridge, Indian Ocean, Western Pacific, Northeast Pacific Rise and East Pacific Rise, characterized by high levels of endemism, with 95\% of the species not shared between provinces (Moalic et al. 2012). Cold seep ecosystems have been grouped into a few provinces: the Gulf of Mexico, Atlantic, Mediterranean, East Pacific and West Pacific (Tyler et al 2003), with low species richness but high endemism (Turnipseed et al. 2003; Tunnicliffe et al. 1998).

The high levels of endemism currently reported for these ecosystems, indicate that vent fauna have in general low dispersal potential, although taxonomic uncertainty might cause an overestimation of endemism (Vrijenhoek 2009). Because access to great depths is extremely challenging, there is insufficient information about species variation in space and time. This knowledge gap might lead to the description, across sites and provinces, of synonymous species (morphologically distinct yet belonging to a single interbreeding species) or on the 
contrary, single species descriptions including undetected cryptic ones (morphologically indistinguishable but reproductively isolated species). To date, population genetics analyses have surprisingly shown a generally high capacity for long-distance dispersal and gene flow for organisms associated with chemosynthetic habitats (Teixeira et al. 2011a, 2012; Van der Heijden et al. 2012; Thaler et al. 2011; Vrijenhoek 2010; Kyuno et al. 2009; Peek et al. 2000), except for some cases of genetic differentiation (Plouviez et al. 2009; Johnson et al. 2006; Hurtado et al. 2004; Jollivet et al 1995). Thus, whether the high endemism reported among seeps and vents reflects speciation and lack of connectivity among habitats, or is partly overestimated by descriptions of synonymous species due to morphological plasticity requires further in-depth investigations (Vrijenhoek 2009; Samadi et al. 2006).

The Atlantic equatorial belt (AEB) has been identified as one of the areas of choice to study connectivity among deep chemosynthetic ecosystems (Tyler et al. 2003). Seep communities have been described along the American and African margins (e.g. Olu et al. 1996; Cordes et al. 2007; Olu et al. 2009) potentially connected through equatorial currents. Genetically and morphologically similar taxa of Bathymodiolinae mussels, were found at seeps from both sides of the Atlantic, raising questions about the past and/or present day connection along the AEB (Olu-Le Roy et al. 2007). A hypothetical west-east passage has been proposed for chemosynthetic species across the equatorial Atlantic, with a possible role of hydrothermal vents distributed along the transform faults of the Mid-Atlantic Ridge (MAR) as conduits to dispersal (Van Dover et al. 2002; Tyler et al. 2003). The most recent biogeographical analysis of taxa across the AEB showed that communities cluster according to depth rather than geographical distances (Olu et al. 2010). Among 72 taxa, only 9 species appeared to be present on both sides of the Atlantic, and the hypothesis of the MAR hydrothermal vents acting as stepping stones for migration between both sides was not supported. Sister species 
117 of mussels of the genus Bathymodiolus are segregated among different types of 118 chemosynthetic ecosystems. This is also the case for shrimp, with Alvinocaris muricola

119 occurring at cold seeps on both sides of the Atlantic and its sister taxa Alvinocaris markensis occurring at vents along the MAR (Olu et al. 2009). However, the presence of A. muricola was once suspected in the Logatchev site of MAR (Shank, pers. comm. in Komai \& Segonzac 2005). More recently, the Vesicomyidae bivalves Calyptogena sp. and Vesicomya sp., now renamed Abyssogena southwardae (Audzijonyte et al. 2012), were recorded for both Western Atlantic seeps and vents of the Mid-Atlantic Ridge, based on morphological traits (Krylova et al. 2010), and also genetic similarities (at the mitochondrial Cytochrome Oxydase subunit I, COI; Decker et al. 2012; Van der Heijden et al. 2012).

To test the hypothesis of large scale dispersal between seeps and vents of the Atlantic equatorial belt we used partial sequences of the mitochondrial cytochrome oxidase subunit I (COI) gene from several morphologically described species of Alvinocarididae shrimps and Vesicomyidae bivalves. To obtain estimates of gene flow across the Atlantic equatorial belt, the shrimp taxa (Alvinocaris sp.) identified as shared among sites on the basis of COI sequence analysis were then further analysed using the nuclear 18S ribosomal RNA gene (18S rRNA) and 9 microsatellite markers.

\section{Materials and Methods}

\section{Sampling and DNA extraction}

The Alvinocarididae shrimp and Vesicomyidae bivalve taxa analyzed in this study were collected from cold seeps of the Eastern (Congo margin) and Western (Gulf of Mexico) 
139 Atlantic and from hydrothermal vents (along the Mid Atlantic Ridge - MAR) during several 140 oceanographic cruises. Three cold seep areas along the Congo margin were sampled during 141 the WACS and the Congolobe cruises including the Regab and the Worm Hole pockmarks 142 (Ondréas et al. 2005; Sahling et al. 2008). The terminal lobes of the Congo deep-sea fan, a 143 sedimentary zone where chemosynthetic species are present were also sampled during these cruises (Sibuet \& Vangriesheim 2009). Shrimp samples were collected using a slurp-gun from the ROV (Remotely Operated Vehicle) Victor or the manned submersible Nautile, and Vesicomyidae bivalves were mainly collected with nets and sometimes embedded in sediment cores. Prior to each dive, the bowls used for collecting the shrimp were aseptically washed with ethanol (96 \%) before being filled with sterile seawater; the nets and cores were similarly cleaned. Once on board, live specimens were either frozen whole or immediately dissected into body parts under sterile conditions and frozen or preserved in $70 \%$ alcohol. DNA extraction was performed using the CTAB (cetyl trimethyl ammonium bromide) method (Doyle \& Doyle 1990) on muscle tissue. Sample sizes are described in Table 1. Abyssogena kaikoi Okutani \& Metivier 1986, Nankai Trough; A. mariana Okutani et al. 2013, from the Shinkai seeps; A. phaseoliformis Metivier et al. 2006, Kurile Trench; A. novacula Krylova et al. 2010, from Peru trench seeps and A. southwardae Krylova et al. 2010, Barbados Accretionary Prism, West Florida Escarpment and Logatchev vent field. We also included an undescribed Abyssogena specimen, from Ryukyu Trench Kojima et al. 2004.

As Genbank contains data obtained prior to the new taxonomic revision, and/or unnamed/ reidentified sequences, we have renamed these sequences (see Table 1) according to their identification in the most recent taxonomic revision (Audzijonyte et al. 2012). This new nomenclature was used throughout the analysis. 
163 In addition, sequences available in GenBank for morphologically identical or closely related 164 species (Table 1) were integrated in the analysis to define clusters of identical or highly 165 similar groups of sequences or taxa, that would support or challenge morphological taxonomy 166 or identification. All species analysed and their locations are detailed in Figure 1 and Table 1.

167 Based on our sequence results (see results below) the Alvinocarididae shrimp were grouped 168 into two ESU (Evolutionary Significant Unit), and one of these (hereafter referred to as ESU 169 1) was further investigated with more detailed microsatellite analyses (sample size permitting 170 this analysis).

Polymerase chain reaction, sequencing and genotyping

173 Part of the mitochondrial COI gene, the $18 \mathrm{~S}$ gene (ca $1.7 \mathrm{~kb}$ ) and 9 microsatellite loci were 174 amplified according to the conditions detailed in Table 2. The PCR amplifications were 175 conducted on a Perkin-Elmer Gene Amp System 7200 (Waltham, MA, USA). PCR products 176 obtained for the mitochondrial and the $18 \mathrm{~S}$ gene were sent to be purified and sequenced 177 commercially at Macrogen, Inc. (Seoul, Korea) and GATC Biotech (Konstanz, Germany), 178 while microsatellite fragments were separated on an ABI 3130 XL automatic sequencer with 179 the internal size standard Rox 350. Alleles were scored using Peak Scanner version 1.0 180 (Applied Biosystems).

Data analysis 
Alignments of nucleotide sequences were constructed with Clustal X version 1.83 using the default parameters (Thompson \& Gibson 1997), and verified by eye in order to maximise positional homology. Only unique haplotypes were included in phylogenetic analyses.

Three different data sets were analysed: (1) partial sequences of the COI gene of 26 Vesicomyidae bivalves (14 from this study) using "undetermined genus" nautilei (former Calyptogena nautilei) as the outgroup produced an alignment of 502 bp; (2) partial sequences of the COI gene of 39 Alvinocarididae shrimps (35 from this study) using Stenopus hispidus as the outgroup produced an alignment of $447 \mathrm{bp}$, and (3) partial sequences of the nuclear 18S rRNA gene of 20 Alvinocarididae shrimps (17 from this study) using Eugonatonotus chacei as the outgroup produced an alignment of $483 \mathrm{bp}$.

Prior to the phylogenetic reconstructions of the Alvinocarididae shrimp, we obtained an initial data set of 198 Alvinocarididae partial COI sequences (28 retrieved from the GenBank representing all available deep-sea chemosynthetic shrimp species), of which we discarded all identical and all highly dissimilar sequences (clustered with ours with a divergence level higher than 4\%), this approach resulted in the final phylogenetic dataset of 39 COI sequences analysed.

The nuclear 18S rRNA data set included three Alvinocaris aff. muricola from West African seeps, four Alvinocaris muricola from the Gulf of Mexico seep, six Alvinocaris markensis from the Logatchev vent field, and four Chorocaris chacei from Lucky Strike vent field. Two sequences retrieved from Genbank: Alvinocaris muricola and Rimicaris hybisae were also included in the nuclear data set (accession numbers detailed in Figure 4). 
The Akaike Information Criterion (Akaike 1973) implemented in MoDELTEST v.3.7 (Posada \& Crandall 1998) was used to determine the evolutionary models that best fit each of the three data sets. PHYML v2.4.4 (Guindon \& Gascuel 2003) was used to estimate the maximum likelihood (ML) trees in all data sets, and to test by nonparametric bootstrap proportions (BPs) the robustness of the inferred trees using 1000 pseudoreplicates. The selected model for the COI Alvinocarididae dataset used in ML analysis was the GTR $+\Gamma$ whereas the JC was the selected model for the nuclear data set. The best-fit evolutionary model for the Vesicomyidae COI data set was the $\operatorname{TrN}+\mathrm{I}$. All ML analyses were carried out on the freely available Bioportal (http://www.bioportal.uio.no).

Bayesian inferences (BI) were conducted with MrBayes v3.1.2 (Huelsenbeck \& Ronquist 2001) by Metropolis coupled Markov chain Monte Carlo (MCMCMC) analyses were run for four million generations, and sampled every 100 generations. Two independent runs were performed to reduce chances of selecting a local but not a global optimum. The burn-in was set to 2000,000 generations and robustness of the inferred trees was evaluated using Bayesian posterior probabilities (BPPs).

The Alvinocarididae shrimp COI dataset was analysed under the GTR $+\Gamma(\mathrm{Nst}=6)$, the best-fit model for the nuclear data set was JC $(\mathrm{Nst}=1)$ and the Vesicomyidae bivalve COI data set was analysed under the $\mathrm{TrN}+\mathrm{I}(\mathrm{Nst}=6)$. All Bayesian analyses were performed on the CCMar Computational Cluster Facility (http://gyra.ualg.pt) at the University of Algarve.

To analyse and illustrate the divergence levels among haplotypes found for the Vesicomyidae bivalves and Alvinocarididae shrimp across sites, median-joining networks were constructed, using the number of mutations as distance, using Network v. 4.1.0.9 (Bandelt et al., 1999) to infer the most parsimonious branch connections between the sampled haplotypes. In this 
analysis higher sample sizes (all available sequences) were used in relation to the maximum likelihood trees obtained for both organisms (bivalves and shrimp). For the network analysis a total of 44 sequences were used to obtain one haplotype network of Abyssogena southwardae (details in Table 1), while for the Alvinocarididae shrimp a total of 199 sequences were used to obtain two haplotype networks (corresponding to ESU 1 and 2; Figure 3), 197 sequences were generated in this study (as explained in the sampling section) and 2 sequences retrieved from GenBank (Rimicaris hybisae and Alvinocaris methanophila). To obtain the haplotype network corresponding to ESU 1, 101 sequences were used (all generated in this study) and for the network corresponding to ESU 2, 98 sequences were used (two of these were retrieved from GenBank as explained above).

\section{Atlantic equatorial belt connectivity of Alvinocaris shrimp (ESU 1)}

The clade we named ESU 1 (Figure 3), which includes Alvinocaris muricola (from West Africa and Gulf of Mexico seeps) and A. markensis (Logatchev vent field) had enough sequences available for further analyses (101 individuals, see results section for details). These were analyzed using ARLEQUIN version 3 (Schneider et al., 2000) to estimate gene diversity and conduct statistical tests on mitochondrial (COI) data.

For each sampling location, the following statistics were computed for mitochondrial data: number of private haplotypes (Nph), haplotype $(h)$ (Nei, 1987) and nucleotide diversities $\left(\pi_{2}\right)$ (Nei, 1987), and mean number of pairwise differences $\left(\pi_{1}\right)$ (Tajima, 1983). To assess population differentiation, pairwise $F_{\text {ST }}$ values were calculated following the method of Hudson et al. (1992) and exact tests of differentiation were conducted following the method of Raymond \& Rousset (1995). 
For demographic analysis we determined Fu’s $F_{S}(F u, 1996)$ and Tajima’s D (Tajima, 1989), which can detect departures from selective neutrality and changes in population size such as expansions or bottlenecks (Tajima, 1996; Fu, 1997). Both statistics are expected to result in negative values after a population expansion (Ray et al., 2003) or a selective sweep, whereas positive values are expected under balancing selection of recent bottlenecks.

To assess asymmetrical gene flow between the seeps and vent sampled, we used MIGRATE version 3.2.16 (Beerli, 2009). This analysis is based on maximum-likelihood (ML) estimates for both migration rates and effective population sizes using a coalescent approach (Beerli \& Felsenstein, 1999). We used an initial random seed number and $\Theta$ and $M$ starting parameters calculated from $F_{\mathrm{ST}}$. As searching strategy we used 40 short chains (4000 trees sampled) and 6 long chains (40 000 trees sampled). For each chain the first 300000 steps were used as a burn-in and adaptive heating was used to ensure an independent, comprehensive search of the parameter space. We performed 4 independent runs and verified their congruence.

For the microsatellite data (9 loci used), the mean number of alleles per locus (allelic diversity), the expected $\left(H_{\mathrm{E}}\right)$ and observed $\left(H_{\mathrm{O}}\right)$ proportion of heterozygotes, and the inbreeding coefficient $\left(F_{\text {IS }}\right)$ were estimated using GENETIX 4.05 (Belkhir et al. 1994-2004). Significance levels were estimated using a permutation approach (1000 permutations). The software GENCLONE (Arnaud-Haond \& Belkhir 2007) was used to calculate standardized allelic richness $\left(A_{\text {rich }}\right)$, to compensate for the unequal sample sizes.

The $F$ estimator of genetic structure $\theta$ (Weir \& Cockerham 1984) was calculated for each locus and over all loci. The probability of the F-statistics being greater than zero was determined by permutation (10 000 replicates) using GENETIX 4.05 (Belkhir et al. 1994- 
2004). Correction for multiple testing was performed using the false discovery rate (FDR) approach (Benjamini \& Hochberg 1995) in the software QVALUE (Storey 2002).

To test for a reduction in effective population size linked to bottleneck or founder events, the Wilcoxon sign-rank test was applied to test for differences between heterozygosities estimated from allele frequencies $\left(H_{\mathrm{E}}\right)$ and from the number of alleles and sample size $\left(H_{\mathrm{Eq}}\right)$. During a bottleneck, allele number decreases faster than heterozygosity, resulting in a transient apparent heterozygosity excess, indicative of a recent bottleneck event (Cornuet \& Luikart 1996) whereas the opposite (allele excess) might occur during a population expansion (Maruyama \& Fuerst 1984). Tests were implemented by BOTTLENECK 1.2.02 (Cornuet \& Luikart 1996) using 1000 iterations. Estimates of $H_{\mathrm{Eq}}$ were calculated under the single-step mutation model (SMM) and the two-phase model (TPM), allowing for 10\% multi-step mutations.

\section{Results}

\section{Vesicomyidae bivalves}

Potential Scale Reduction Factors in Bayesian analyses (all data sets) were 1.00, indicating full convergence of the runs (Gelman and Rubin, 1992). Phylogenetic relationships within the genus Abyssogena were mostly unresolved and only two well-supported clades were recovered both in the ML and BI analyses (Figure 2). One corresponded to A. mariana from the Shinkai Seep Field (Pacific Ocean) and the other clade included the samples of $A$. southwardae from the Lobes of the Congo deep-sea fan and West Florida Escarpment. Sequence divergence between the 20 individuals of A. southwardae collected at the Western, Eastern and Mid Atlantic Ridge was very low (less than 1.2\% maximum divergence). These clustered into three groups that were geographically mixed and poorly statistically supported. 
No identical sequences of $A$. southwardae were detected among those available in GenBank for Western Atlantic cold seeps (Florida Escarpment and Barbados Accretionary Prism), Mid Atlantic Ridge (Logatchev vent field) nor the ones generated in this study from Eastern Atlantic cold seeps (Western Africa cold seeps). However the haplotypes from Florida Escarpment and MAR appear in a central position in the network, intermediate between several haplotypes retrieved from Western African cold seeps (Figure 5). While the two Barbados samples of A. southwardae (JX196983; AF008279) displayed a large divergence between themselves (5 point mutations); the JX196983 sequence appeared in the haplotype network between the AF008279 sequence and the other $A$. southwardae sequences of the MAR. The JX196983 sequence displayed 1 point mutation divergence from the MAR and a 2 point mutation divergence from the Florida A. southwardae. Of the 20 A. southwardae sequences analysed of the Atlantic ocean, the AF008279 Barbados sequence was the most divergent (1.2\% maximum divergence).

\section{Alvinocarididae shrimp}

Potential Scale Reduction Factors in Bayesian analyses (all data sets) were 1.00, indicating full convergence of the runs (Gelman and Rubin, 1992). Both the ML and BI trees based on the COI gene obtained from several Alvinocarididae shrimp species exhibited two well supported and very divergent clades (Figure 3). The first clade, which we call ESU 1 (Evolutionary Significant Unit 1, Figure 3), includes all Alvinocaris muricola and A. markensis from seeps and vents of the Atlantic. The second clade (ESU 2, Figure 3) includes specimens with sequence divergence bellow 2\%. This comprises Chorocaris chacei from the MAR vents, the newly described Rimicaris hybisae (which shares some identical sequences with Chorocaris chacei but still displayed a maximum divergence of 0.8\%) from the Cayman Ridge vents and Alvinocaris methanophila (1.4\% divergence with Chorocaris chacei) from 
Blake Ridge seeps. In accordance with these results, the ML tree obtained using the $18 \mathrm{~S}$ gene clusters the same taxa as the COI gene for the second clade (ESU 2) with high support (Figure 4), while it lacked resolution in the first clade (ESU 1; Figure 4).

In ESU 2 (Chorocaris/Rimicaris/A. methanophila) 15 distinct haplotypes were recovered (Figure 5) out of the 98 sequences analysed for COI. Of these, 10 haplotypes were unique (66.7\%) and the remaining 5 that were shared, i.e. haplotypes displayed by more than one individual, belonged to Chorocaris chacei from the Logatchev and Lucky Strike vent fields (accession numbers KC840928 to KC840940). The Rimicaris hybisae sequence had only one point mutation from a Chorocaris chacei haplotype and only two point mutations from the most common haplotype. Similarly, the results for the $18 \mathrm{~S}$ gene also revealed very low divergence between Rimicaris hybisae and Chorocaris chacei (0 to $0.4 \%$ divergence). The Alvinocaris methanophila haplotype was more distant from the centre of the haplotype network, with eight point mutations from the most common haplotype (Figure 5). Yet, the ML tree (Figure 3) clusters this specimen in ESU 2 making the genus Alvinocaris (ESU 1) non monophyletic, an issue that should be verified with nuclear sequence data.

\section{$\underline{\text { Population analysis }}$}

For the ESU 1 clade, which had sufficient sampling size for a population analysis, a total of 49 haplotypes were recovered out of the 101 individuals analysed, all belonging to the genus Alvinocaris (A. aff. muricola from West African seeps, A. muricola from the Gulf of Mexico seep and A. markensis from the Logatchev vent field; Figure 5) sampled across the Atlantic Equatorial Belt. A total of 45 (91.8 \%) haplotypes were “private” (Figure 5; accession numbers: KC840879 to KC840927). The most common haplotype was present in all populations sampled across the whole study region, and was central to all other haplotypes, 
most of these represented by a single individual and divergent by a single or double point mutation, leading to the central haplotype as the core of a star-like topography (Figure 5).

Haplotype diversity $(h)$ was high for all populations, ranging from 0.80 (West Africa seeps, $n=78$ ) to 0.96 (Logatchev vent, $n=11$ ). In contrast with these rather high values of haplotype diversity, nucleotide diversity $\left(\pi_{2}\right)$ was however low, ranging from 0.0037 to 0.005 (Table 3). Multilocus genotypes at the 9 microsatellite loci analysed for 98 Alvinocaris shrimp (ESU1) from the three sites across the Atlantic equatorial belt (A. muricola from the Gulf of Mexico and West Africa and A. markensis from Logatchev) also revealed high genetic diversity. The mean number of alleles per locus increased with sample size (Table 4), but the standardized allelic richness $\left(A_{\text {rich }}\right)$ did not show major trends, ranging from 4.67 (Logatchev) to 5.47 (Gulf of Mexico). Unbiased heterozygosity $\left(H_{\mathrm{E}}\right)$ varied between 0.59 (West Africa) and 0.65 (Logatchev) and the observed heterozygosity $\left(H_{O}\right)$ varied between 0.52 (Gulf of Mexico) and 0.62 (Logatchev). The tests for Hardy-Weinberg equilibrium revealed heterozygote deficiency, after correction for multiple tests for both seep sites (Table 4) except for the Logatchev vent which showed no significant departure from equilibrium. Significant $F_{\text {IS }}$ values were comprised between 0.09 and 0.18 and were homogeneous across loci.

Demographic analyses suggested the occurrence of population expansions, these were significant for all studied sites when analysing mitochondrial data, with significant negative values for Tajima's D and Fu's $F_{\mathrm{S}}$ (Table 3), while with microsatellite data (bottleneck tests) only the West African cold seep population revealed a significant signature of population expansion (for all mutation models tested), as the expected heterozygosity estimated from allele frequencies $\left(H_{\mathrm{E}}\right)$ was significantly lower than estimates based on the number of alleles and sample size $\left(H_{\mathrm{Eq}}\right)(\mathrm{p}<0.02)$. 
372 Pairwise comparisons between populations from the Gulf of Mexico seeps and the other two

373 regions (Logatchev vent and West Africa seeps) revealed no differentiation (pairwise $F_{\mathrm{ST}}$ for 374 COI haplotypes not significantly different from zero; $\mathrm{p}>0.05$ ) (Table 5). However they were 375 significant $(\mathrm{p}<0.05)$ between the West Africa seeps and the Logatchev vent (Table 5). The 376 pairwise $F_{\mathrm{ST}}$ estimates based on microsatellite loci revealed a similar pattern although with 377 low but significant values between the West Africa seeps and the two other sites (Gulf of 378 Mexico and Logatchev vent), after q-value correction for multiple tests (Table 5). 379 Accordingly, the results from the Bayesian analysis performed with MIGRATE (Table 6) 380 supported, consistently across the independent runs, the occurrence of high gene flow from 381 the Logatchev vent to the Gulf of Mexico seeps.

382 For the ESU 2 clade, only Chorocaris chacei had sufficient sampling size for a population 383 analysis. The pairwise $F_{\mathrm{ST}}$ estimate based on COI, between the two MAR vent locations, was 384 very low and not significant $\left(F_{\mathrm{ST}}=0.00017 ; \mathrm{p}>0.05\right)$. 


\section{Discussion}

386

387

The results reported here reveal large scale connectivity across distinct and patchily distributed chemosynthetic ecosystems. This supports the existence of efficient mechanisms facilitating dispersal and localization of suitable habitats. These findings also raise questions regarding the accuracy of endemism estimates, given our limited knowledge of ecosystems and communities distributed on the bottom of the oceans. We provide evidence for the occurrence of synonymous species for three of the taxa analysed in this study, one Vesicomyidae bivalve and two Alvinocarididae shrimp taxa, shared between hydrothermal vents and cold-seeps across the entire Atlantic Equatorial Belt. This effect creates biases in the evaluation of community composition, diversity and connectivity across deep-sea ecosystems. The description of the same taxa or genetic entities under distinct species and genus names also prevents analyses of dispersal levels and directions across the entire distribution of the taxon or meta-population.

Vesicomyidae bivalve connectivity

The molecular characterization of the vesicomyid A. southwardae assigned to Calyptogena sp., was first conducted on specimens from the Western Atlantic seeps of Barbados and the Florida Trench (Peek et al. 1997), and later found to be similar to specimens from the MAR Logatchev vents (Peek et al. 2000). Its morphological description (Krylova et al. 2010) also included specimens from the Vema fracture zone and empty valves from the Henry seamount, located close to the Canary Islands at $3500 \mathrm{~m}$ depth. Further molecular studies report this species at recently discovered sites in the South MAR hydrothermal vents (Stewart et al. 2008; Van der Heijden et al. 2012). Our study is the first record of this species from the Eastern Atlantic African cold seeps. Although no shared haplotypes were observed between 
regions, the few sequences available from GenBank for the Mid and Western Atlantic are evolutionarily close to those reported here from African seeps, indicating that this might be the same species across all the AEB. Only one of the A. southwardae from the Barbados seeps was slightly more distant but still exhibited relatively low genetic divergence from the others (less than $1.2 \%$, the maximum divergence level found among the sequences analysed), suggesting that they might all belong to the same taxon. The analysis of more samples, especially from those regions poorly represented in GenBank, would help to elucidate whether there are unsampled shared haplotypes across the AEB, or if, on the contrary, the low divergence levels reflect recent differentiation among those sites.

Even with the extremely low sampling sizes available, it was already possible to reveal a close relationship among all sites, suggesting large-scale connectivity for this species across the Atlantic. Indeed, Vesicomyidae bivalves are distributed worldwide and the genus Abyssogena in particular has representatives in at least two Oceans (Atlantic and Pacific; Krylova \& Sahling 2010; Figure 2). Other Vesicomyidae bivalve species shared across oceans are also genetically similar, with several species displaying a trans-Pacific or Indo-Pacific distribution (Kojima et al. 2004; Audzijonyte et al. 2012; Decker et al. 2012; Van der Heijden et al. 2012; Figure 2). These results indicate extremely large-scale dispersal capacity. This might have been either followed by persistent connectivity or, if isolated, then the divergence was too recent to be detected on the basis of mitochondrial sequences alone.

\section{Alvinocarididae shrimp connectivity}

Our data on the Atlantic Alvinocarididae shrimp revealed two well-supported clades shared across the Atlantic, each composed by samples from seeps and vents. The first clade (ESU 1) comprised Alvinocaris muricola from the Western and Eastern Atlantic seeps and Alvinocaris 
markensis from the MAR vents. We show here that these are synonymous taxa, with shared mitochondrial haplotypes and identical microsatellite polymorphism across the entire AEB including vents and seeps. Perhaps more surprisingly, the second clade (ESU 2) comprised specimens from different genera (Chorocaris chacei, Rimicaris hybisae and Alvinocaris methanophila). These showed very low genetic divergence at levels similar to divergence between individuals of the same species. We posit that these taxa belong to the same genus, possibly even the same species.

In the genus Alvinocaris of the AEB (ESU 1), the hypothesis of synonymous species with high connectivity between all geographic locations was further supported by the intermingled distribution of haplotypes originating from different regions in a star-like haplotype network, with extremely low and mostly non-significant differentiation for both mtDNA and microsatellite data. The lack of, or very low genetic differentiation found between sites was not due to low genetic diversity, as the 101 Alvinocaris individuals from the three localities across the Atlantic had even higher genetic diversity, than the high levels revealed for the shrimp species Rimicaris exoculata of the Mid-Atlantic Ridge (Teixeira et al. 2011a; 2012). At most, low sampling sizes for the Western and Central Atlantic could have contributed to the non-rejection of the null hypothesis of panmixia. Yet levels of $F_{\mathrm{ST}}$ were so low, that even if increasing sampling size would make them significantly different from zero, they would still be very low levels of differentiation. These results, together with the lack of genetic differentiation also found in shrimp from clade ESU 2 of the MAR vents, support the occurrence of large scale effective migration across the Atlantic Ocean.

\section{Demographic effects}


For a species to persist as a single genetic entity over a large geographical range in a patchy habitat, gene flow between the separated populations must be high enough to compensate the differentiation originated by random genetic drift within isolated sites. However, a similar signature of low genetic differentiation may also arise when populations have a recent common origin (typical of recently colonized novel habitats; e.g. Neiva et al. 2012) and/or exhibit high effective population sizes limiting the effect of drift and resulting in incomplete lineage sorting despite a lack of connectivity.

Both Vesicomyidae bivalves and Alvinocarididae shrimp have been reported to display large population densities (>1000 individuals $/ \mathrm{m}^{2}$; Tyler \& Young 1999, Copley et al. 1997). In the absence of temporal fluctuation or significant variance in reproductive success, high population densities might reflect large effective population sizes. However, the star-like topology of our haplotype network of the Alvinocaris shrimp together with the neutrality and bottleneck tests, suggest a recent small effective population size followed by expansion. Such events cause instantaneous drift in each independent population which would generate differentiation among populations, unless counteracted by connectivity. The joint observation of large-scale homogeneity and signatures of recent demographic events invalidates the hypothesis of large effective population size hiding ongoing divergence. Instead, it supports the hypothesis that contemporary high connectivity across the Atlantic seeps and vents is the most likely explanation for the results reported here.

More taxa should be investigated in the future to further test for the role of MAR as a significant stepping stone between Atlantic seep communities. Our results confirm the role of Mid-Atlantic vents as a stepping stone for at least the two taxa that had sufficient sampling to allow the test of this hypothesis, among the 72 reported thus far from Atlantic seeps (Olu et al. 2010). Additionally, our results highlight that the possible large scale overall connectivity 
477 picture might be obscured by the suggested occurrence of synonymous species. In particular,

478

479 distinct species (and sometimes genus) names discourage genetic studies to address

connectivity. Indeed, recently an identical mitochondrial background was revealed among

three distinct morphologically described species of tubeworms, Escarpia sp., from seeps

along the Atlantic and the Eastern Pacific. This finding triggered population genetic studies

which revealed large scale dispersal at regional scales (Cowart et al., in press; doi:

10.1111/mec.12379).

\section{Connectivity}

Many factors play a role in effective dispersal, such as fecundity, size of the source population, timing of reproduction, type of larval development, mortality and oceanic currents (Scheltema 1986). Large-scale dispersal has been inferred for many vent organisms regardless of their differences in early life history traits (see review Vrijenhoek 2010) that could influence dispersal ability, suggesting that these are poor predictors of effective dispersal. Indeed Abyssogena southwardae and Alvinocaris spp. share a wide distribution and patterns of contemporary gene flow across the Atlantic, yet exhibit strikingly distinct larval development.

The reproductive biology of Vesicomyidae bivalves is poorly studied and undescribed for Abyssogena species. However earlier studies showed that vesicomyid oocytes are usually $\sim 200 \mu \mathrm{m}$ in diameter, possibly supporting a lecitotrophic development (Lisin et al. 1997; Tyler \& Young 1999; Parra et al. 2009). Lecitotrophs are generally assumed to be poor dispersers, but they can have very long pelagic residence times (Shilling \& Manahan 1994) and eggs with a greater amount of yolk. Higher reserves may even represent an advantage by 
providing nourishment during long-distance dispersal across inhospitable habitats. But to date, no data are available regarding the larval dispersal capacities of Vesicomyidae bivalves.

Alvinocarididae shrimp have been mostly shown to exhibit planktonic larval development with relatively low fecundity ( 400 eggs per female). The scarce information available suggests that the development could take place at shallower depths (Pond et al. 2000). For the species Rimicaris exoculata, it has been hypothesised that females release their eggs into vent plumes before hatching, as plankton samples at Broken Spur vent field contained eggs, which represented 95\% of the biomass (Tyler \& Young 1999). Also in the Atlantic, larval stages of Alvinocaris sp. and Chorocaris sp. have been captured in trawls at mid-water depths and at great distances from known vents (Herring \& Dixon 1998). All available data therefore seem to support dispersal potential in the three dimensions of the Atlantic water masses, for at least these Alvinocarididae shrimp species.

Across the Atlantic Equatorial Belt the longitudinal flow of the North Atlantic Deep Water, enhanced by equatorial intermediate jets could theoretically provide a connection pathway along the Equator (Arhan et al. 1998). However, these deep currents have very low velocities, and the time taken to cross the Atlantic may represent a few years. These low velocities may at least in part be compensated by their low temperatures that should slow down larval development, and delay metamorphosis (O'Connor et al. 2007). Besides, warmer and faster surface currents could offer enhanced crossing speed, on the order of few months (Olu et al. 2010). A study on dispersal of deep-sea larvae (Young et al. 2012) among seep communities along the Atlantic American margins indeed showed that shallow dispersal provided greater travelled distances for some of the species analysed. This study further supported that the eastward drift in the North Atlantic is unlikely to carry larvae from North America seeps to Western Africa. The authors suggested that if there is genetic exchange across the Atlantic it 
is most likely unidirectional, from East to West in the Equatorial current system (Young et al. 2012). Accordingly our Bayesian analysis (MIGRATE) of mitochondrial data from Alvinocaris seems to consistently support a westward migration from the Mid-Atlantic Ridge to seeps in the Gulf of Mexico. As deep-sea shrimp have been reported as possibly having an ontogenetic vertical migration (Herring \& Dixon 1998), they may take advantage of the faster shallow currents across the Equator.

A wide range of biological mechanisms and oceanographic pathways therefore exist that may facilitate, speed up or lengthen the duration of dispersal, and contribute to explain the large scale dispersal of larvae across the Atlantic deep sea ecosystems. Yet in a three dimensional ocean, considering the extremely fragmented distribution of vents and seeps, the probability of an individual reaching a suitable chemosynthetic habitat after being diluted in an incommensurable volume of water seems infinitesimal. The existence of dispersal mechanisms such as those delaying metamorphosis (as found for an alvinellid polychaete, Pradillon et al. 2005), or actively guiding larvae (or adults in cases where they are significantly mobile) towards suitable habitat, or through vertical migrations that catch more favourable currents, seem a more parsimonious additional explanation. Indeed, deep-sea larvae can potentially move into water of different temperatures and in some cases different pressures; this may lead to alterations in metabolism, feeding rate, and other vital processes (Young et al. 1996, 1998), extending pelagic larval durations (PLD) (O’Connor et al. 2007). A hypothesis of active directed migration could involve the detection of stimuli such as water chemistry, sound, polarized light, current direction, magnetism and water pressure, as found for other organisms (Kingsford et al. 2002), or a combination of such mechanisms with extremely delayed larval development linked to low temperatures in the deep-sea (O’Connor et al. 2007). 
548 Another non-exclusive hypothesis to explain high connectivity is the possible occurrence of 549 more stepping stone habitats than acknowledged. Additional favourable habitats may exist 550 that might have remained undetected thus far due to an extremely low mapping and 551 exploration effort, though extremely valuable. This might cause an erroneous appraisal of 552 deep-sea species ranges, endemicity and connectivity (Audzijonyte \& Vrijenhoek 2010) due 553 to very low, spatially scattered and ecosystem-biased, sampling coverage. Indeed, Samadi et 554 al. (2006) showed that high endemism previously reported for some Pacific seamounts was 555 for a large number of taxa an artefactual observation due to low sampling densities focused on a limited geographical area. By increasing sampling pressure at larger geographical scales, these authors demonstrated that most presumed endemic species were also found in other habitats, leading them to propose that seamounts are biodiversity rather than endemism hot spots.

Exploration of deep-sea habitats is very biased toward seamounts, active vents and seeps, because these oases of life can be detected from the surface due to the geological anomalies with which they are associated. The present-day knowledge of the distribution of reducing environments in the whole deep-sea is largely underestimated (Audzyjonite \& Vrijenhoek 2010). However whale- and wood-falls encountered by chance harboured chemosynthetic communities similar to those observed at seeps and vents. These temporary ecosystems may act as stepping stones (Black et al. 1997) dispersed across the seabed ensuring connectivity among chemosynthetic ecosystems. Indeed, several species of Vesicomyidae bivalves have been for example described from deep-sea expeditions of the early $20^{\text {th }}$ century (e.g. Valdivia, Thiele \& Jackel 1931) without description of their biotope (Cosel \& Olu 2009) and 570 occasionally these old records are identified as the same species as those from cold seeps (e.g.

571 Christineconcha regab from the Bay of Biscay and the Regab pockmark; Krylova \& Cosel 
2011). Incidentally, on an artificial wood deployment about 300 m away from any active site near Logatchev (Mid-Atlantic Ridge), Alvinocaris shrimp were observed but unfortunately not collected (SH, pers. obs.). The large scale dispersal observed in previous studies and confirmed here across the whole Atlantic Ocean raises the question of how many suitable habitats not associated to easily detectable geological anomalies might remain to be discovered in the depths of the oceans in order to gain a global picture of deep sea biodiversity and biogeography.

\section{Acknowledgements}

The authors wish to thank Rui Candeias, Rita Castilho and Filipe Alberto for technical help; the captains, chief scientists (K. Olu, C. Rabouille, J. Sarrazin, Y. Fouquet, and C.R. Fisher) and crews of the WACS, Congolobe, Momareto, Serpentine, and Expedition to the Deep Slope cruises; Gareth Pearson for the English revision of the manuscript and Asta Audzijonyte and two anonymous reviewers for their helpful suggestions and comments on earlier versions of this manuscript. Collections from the Gulf of Mexico were supported by the US Bureau of Ocean Energy Management contract M05PC00018, and the National Oceanic and Atmospheric Administration's Office of Ocean Exploration and Research (NOAA OER). S.T. and RLC were supported by a postdoctoral fellowship from FCT, Portuguese Science Foundation and ESF (European Social Fund), C.D. was supported by a postdoctoral fellowship from the national ANR project Congolobe. S.T., and S.A-H. were supported by national ANR projects DeepOases, Congolobe and the FP7 EU project Hermione. 


\section{References}

595

596

597

598

599

600

601

602

603

604

605

606

607

608

609

610

611

612

613

Audzijonyte A, Krylova EM, Sahling H, Vrijenhoek RC (2012) Molecular taxonomy reveals broad trans-oceanic distributions and high species diversity of deep-sea clams (Bivalvia:

Vesicomyidae: Pliocardiinae) in chemosynthetic environments. Systematics and Biodiversity, 10, 403-415.

Audzijonyte A, Vrijenhoek R (2010) When gaps really are gaps: statistical phylogeography of hydrothermal vent invertebrates. Evolution, 64, 2369-2384.

Andersen AC, Hourdez S, Marie B, Jollivet D, Lallier FH, et al. (2004) Escarpia southwardae sp. nov., a new species of vestimentiferan tubeworm (Annelida, Siboglinidae) from West African cold seeps. Canadian Journal of Zoology, 82, 980-999.

Akaike H (1973) Information Theory and an Extension of the Maximum Likelihood Principle. In: CSAKI. BNPaF, ed. Second International Symposium on Information Theory Budapest Akademiai Kiado. pp 267-281.

Arhan M, Mercier H, Bourles B, Gouriou Y (1998) Two hydrographic sections across the Atlantic at $7^{\circ} 30 \mathrm{~N}$ and $4^{\circ} 30 \mathrm{~S}$. Deep-Sea Research, 45, 829-872.

Arnaud-Haond S, Belkhir K (2007) GENCLONE: a computer program to analyse genotypic data, test for clonality and describe spatial clonal organization. Molecular Ecology Notes, 7, $15-17$.

Bachraty C, Legendre P, Desbruyères D (2009) Biogeographic relationships among deep-sea hydrothermal vent faunas at global scale. Deep-Sea Research I, 56, 1371 -1378. 
Baco AR, Smith CR, Peek AS, Roderick GK, Vrijenhoek RC (1999) The phylogenetic relationships of whale-fall vesicomyid clams based on mitochondrial COI DNA sequences. Marine Ecology Progress Series, 182, 137- 147.

Bandelt HJ, Forster P, Röhl A (1999) Median-joining networks for inferring intraspecific phylogenies. Molecular Biology and Evolution, 16, 37-48.

Beerli P, Felsenstein J (1999) Maximum-likelihood estimation of migration rates and effective population numbers in two populations using a coalescent approach. Genetics, 152, $763-773$.

Beerli P (2009) How to use migrate or why are markov chain monte carlo programs difficult to use? In: Bertorelle G, Bruford MW, Hau_e HC, Rizzoli A, Vernesi C, editors. Population Genetics for Animal Conservation. Cambridge University Press, Cambridge UK volume 17, 42-79.

Belkhir K, Borsa P, Chikhi L, Raufaste N, Bonhomme F (1996) GENETIX 4.05, logiciel sous Windows TM pour la génétique des populations. Laboratoire Génome, Populations, Interactions, CNRS UMR 5000, Université de Montpellier II, Montpellier (France). Benjamini Y, Hochberg Y (1995) Controlling the false discovery rate: a practical and powerful approach to multiple testing. Journal of the Royal Statistical Society B, 57, 289-300. Bergquist DC, Williams FM, Fisher CR (2000) Longevity record for a deep-sea invertebrate. Nature, 403,499- 500 .

Black MB, Halanych KM, Maas PAY, Hoeh WR, Hashimoto J, Desbruyères D, R. A. Lutz RA, Vrijenhoek RC (1997) Molecular systematics of vestimentiferan tubeworms from hydrothermal vents and cold-water seeps. Marine Biology, 130, 141- 149. 
Copley JTP, Tyler PA, Murton BJ, van Dover CL (1997) Spatial and interannual variation in the faunal distribution at Broken Spur vent field (29N, Mid-Atlantic Ridge). Marine Biology, 129, 723-733.

Cordes EE, Carney SL, Hourdez S, Carney RS, Brooks JM, Fisher CR (2007) Cold seeps of the deep Gulf of Mexico: Community structure and biogeographic comparisons to Atlantic equatorial belt seep communities. Deep Sea Research Part I: Oceanographic Research Papers, 54, 637-653.

Corliss JB, Dymond J, Gordon LE, Edmond JM, Von Herzen RP, Ballard, et al. (1979) Submarine thermal springs on the Galapagos Rift. Science, 203, 1073-1083.

Cornuet JM, Luikart G (1996) Description and power analysis of two tests for detecting recent population bottlenecks from alleles frequency data. Genetics, 144, 2001-2004.

Cosel Rv, Olu K (2009) Large Vesicomyidae (Mollusca: Bivalvia) from cold seeps in the Gulf of Guinea off the coasts of Gabon, Congo and northern Angola. Deep Sea Research Part II: Topical Studies in Oceanography, 56, 2350-2379.

Craddock C, Hoeh WR, Gustafson RG, Lutz RA, Hashimoto J, Vrijenhoek RJ (1995)

Evolutionary relationships among deep-sea mytilids (Bivalvia: Mytilidae) from hydrothermal vents and cold-water methane/sulfide seeps. Marine Biology, 121, 477- 485.

Decker C, Olu K, Cunha RL, Arnaud-Haond S (2012) Phylogeny and Diversification Patterns among Vesicomyid Bivalves. PLoS ONE, 7, e33359.

Desbruyères D, Almeida A, Biscoito M, Comtet T, Khripounoff A, Le Bris N, Sarradin PM, Segonzac M (2000) A review of the distribution of hydrothermal vent communities along the northern Mid-Atlantic Ridge: dispersal vs. environmental controls. Hydrobiologia, 440, 201216.

Doyle JJ, Doyle JL (1990) Isolation of plant DNA from fresh tissue. Focus, 12, 13-15. 
660

661

662

663

664

665

666

667

668

669

670

671

672

673

674

675

676

677

678

679

680

681

682

Folmer O, Hoeh WR, Black MB, Vrijenhoek RC (1994) Conserved primers for PCR amplification of mitochondrial DNA from different invertebrate phyla. Molecular Marine Biology and Biotechnology, 3, 294-299.

Fu YX (1996) New statistical tests of neutrality for DNA samples from a population. Genetics, 143, 557-570.

Fu YX (1997) Statistical tests of neutrality of mutations against population growth, hitchhiking and background selection. Genetics, 147, 915-925.

Gelman A, Rubin D (1992). A Single Series from the Gibbs Sampler Provides a False Sense of Security. In: Bernardo JM, Berger J, Dawid AP, Smith AFM. Bayesian Statistics 4. New York, Oxford University Press, 625-631.

Guindon S, Gascuel O (2003) A simple, fast and accurate algorithm to estimate larges phylogenies by maximum likelihood. Systematic Biology, 52, 696-704.

Hecker B (1985) Fauna from a cold sulphur seep in the Gulf of Mexico: comparison with hydrothermal vent communities and evolutionary implications. Bulletin of the biological Society of Washington, 6,465 -474.

Herring PJ, Dixon DR (1998) Extensive deep-sea dispersal of postlarval shrimp from a hydrothermal vent. Deep-Sea Research I, 45, 2105-2118.

Hudson RR, Slatkin M, Maddison WP (1992) Estimation of levels of gene flow from DNAsequence data. Genetics, 132,583-589.

Huelsenbeck JP, Ronquist FR (2001). MrBayes: Bayesian inference of phylogeny. Bioinformatics, 17, 754-755.

Hurtado L, Lutz R, Vrijenhoek R (2004) Distinct patterns of genetic differentiation among annelids of eastern Pacific hydrothermal vents. Molecular Ecology, 13, 2603-2615. 
Johnson SB, Young CR, Jones WJ, Waren A, Vrijenhoek RC (2006) Migration, isolation, and speciation of hydrothermal vent limpets (Gastropoda; Lepetodrilidae) across the Blanco transform fault. The Biological Bulletin, 210, 140-157.

Jollivet D, Desbruyères D, Bonhomme F, Moraga D (1995) Genetic differentiation of deepsea hydrothermal vent alvinellid populations (Annelida: Polychaeta) along the East Pacific Rise. Heredity, 74, 376-391.

Jollivet D, Empis A, Baker MC, Hourdez S, Comtet T, et al. (2000) Reproductive biology, sexual dimorphism, and population structure of the deep-sea hydrothermal vent scale-worm, Branchipolynoe seepensis (Polychaeta: Polynoidae). Journal of the Marine Biology Association of the United Kingdom, 80, 55-68.

Kingsford MJ, Leis JM, Shanks A, Lindeman KC, Morgan SG, et al. (2002) Sensory environments, larval abilities and local self-recruitment. Bulletin of Marine Science, 70, 309 340.

Kojima S, Fujikura K, Okutani T (2004) Multiple trans-Pacific migrations of deep-sea vent:seep-endemic bivalves in the family Vesicomyidae. Molecular Phylogenetics and Evolution, 32, 396-406.

Komai T, Segonzac M (2005) A revision of the genus Alvinocaris Williams and Chace (Crustacea: Decapoda: Caridea: Alvinocaridea), with descriptions of a new genus and a new species of Alvinocaris. Journal of Natural History, 39, 1111-1175.

Krylova E, Cosel Rv (2011) A new genus of large Vesicomyidae (Mollusca, Bivalvia, Vesicomyidae, Pliocardiinae) from the Congo margin, with the first record of the subfamily Pliocardiinae in the Bay of Biscay (northeastern Atlantic). Zoosystema, 33, 83-99 Krylova EM, Sahling H (2010) Vesicomyidae (Bivalvia): Current Taxonomy and Distribution. PLoS ONE, 5(4): e9957. doi:10.1371/journal.pone.0009957. 
Krylova EM, Sahling H, Janssen R (2010) Abyssogena: a new genus of the family Vesicomyidae (Bivalvia) from deep water vents and seeps. Journal of Molluscan Studies, 76, 107-132.

Kyuno A, Shintaku M, Fujita Y, Matsumoto H, Utsumi M, Watanabe H, Fujiwara Y, Miyazaki J-I (2009) Dispersal and Differentiation of Deep-Sea Mussels of the Genus Bathymodiolus (Mytilidae, Bathymodiolinae). Journal of Marine Biology doi: 10.155/2009/625672.

Lisin S, Barry JP, Harrold C (1997) Reproductive biology of Vesicomyid clams from cold seeps in Monterey Bay, California. American Society of Zoologists: 50.

López-García P, Philippe H, Gail F, Moreira D (2003) Autochthonous eukaryotic diversity in hydrothermal sediment and experimental microcolonizers at the Mid-Atlantic Ridge. Proceedings of the National Academy of Sciences USA, 100, 697-702.

Maruyama T, Fuerst PA (1984) Population bottlenecks and non-equilibrium models in population genetics. I. Allele numbers when populations evolve from zero variability. Genetics, 108, 745-763.

McLean JH (1985) Preliminary report on the limpets at hydrothermal vents. Bulletin of the biological Society of Washington, 6, 159-166

Moalic Y, Desbruyères D, Duarte CM, Rozenfeld AF, Bachraty C, Arnaud-Haond S (2012) Biogeography Revisited with Network Theory: Retracing the History of Hydrothermal Vent Communities. Systematic Biology, 61, 127- 137.

Nei M (1987) Molecular evolutionary genetics. Columbia University Press,New York. Neiva J, Pearson GA, Valero M, Serrão EA (2012) Drifting fronds and drifting alleles: range dynamics, local dispersal and habitat isolation shape the population structure of the estuarine seaweed Fucus ceranoides L. Journal of Biogeography, DOI: 10.1111/j.13652699.2011.02670.x. 
Nye V, Copley J, Plouviez S (2012) A new species of Rimicaris (Crustacea: Decapoda: Caridea: Alvinocarididae) from hydrothermal vent fields on the Mid-Cayman Spreading Centre, Caribbean. Journal of the Marine Biological Association of the United Kingdom, doi:10.1017/S0025315411002001.

O’Connor MI, Bruno JF, Gaines SD, Halpern BS, Lester SE, Kinlan BP, Weiss JM (2007) Temperature control of larval dispersal and the implications for marine ecology, evolution, and conservation. Proceedings of the National Academy of Sciences USA, 104, 1266-1271.

Ohara Y, Reaganc MK, Fujikura K, Watanabe H, Michibayashi K, et al. (2012) A serpentinite-hosted ecosystem in the Southern Mariana Forearc. Proceedings of the National Academy of Sciences USA, 109, 2831- 2835.

Okutani T, Koshi-Ishi T, Sato T, Imai T, Kato C (2009) Vesicomyid Fauna in the Chishima (Kurile) Trench: Occurrences of a New Taxon and Calyptogena extenta. Venus, 68, 15-25. Okutani T, Fujikura K, Watanabe H, Ohara Y (2013) Calyptogena (Abyssogena) mariana: Discovery of a new vesicomyid clam from the Mariana Trench. VENUS, 71, 39-47. Olu K, Sibuet M, Harmegnies F, Foucher J-P, Fiala-Medioni A (1996) Spatial distribution of diverse cold seep communities living on various diapiric structures of the southern Barbados prism. Progress in Oceanography, 38, 347-376.

Olu-Le Roy K, von Cosel R, Hourdez S, Carney SL, Jollivet D (2007) Amphi-Atlantic coldseep Bathymodiolus species complexes across the equatorial belt. Deep-Sea Research I, 54, $1890-1911$.

Olu K, Caprais JC, Galéron J, Causse R, Cosel R von, et al. (2009) Influence of seep emission on the non-symbiont-bearing fauna and vagrant species at an active giant pockmark in the Gulf of Guinea (Congo-Angola margin). Deep Sea Research Part II: Topical Studies in Oceanography, 56, 2380-2393. 
Olu K, Cordes EE, Fisher CR, Brooks JM, Sibuet M, et al. (2010) Biogeography and Potential Exchanges Among the Atlantic Equatorial Belt Cold-Seep Faunas. PLoS ONE, 5, e11967.

Ondréas H, Olu K, Fouquet Y, Charlou JL, Gay A, Dennielou B, et al. (2005) ROV study of a giant pockmark on the Gabon continental margin. Geo-Marine Letters, 25, 281-292.

Parra M, Sellanes J, Dupré E, Krylova EM (2009) Reproductive characteristics of Calyptogena gallardoi (Bivalvia: Vesicomyidae) from a methane seep area off Concepcion, Chile. Journal of the Marine Biological Association of the United Kingdom, 89, 161-169. Peek AS, Gustafson RG (1997) Evolutionary relationships of deep-sea hydrothermal vent and cold-water seep clams (Bivalvia: Vesicomyidae): results from the mitochondrial cytochrome oxidase subunit I. Marine Biology, 130, 151-161.

Peek AS, Gaut BS, Feldman RA, Barry JP, Kochevar RE, et al. (2000) Neutral and nonneutral mitochondrial genetic variation in deep-sea clams from the family Vesicomyidae. Journal of Molecular Evolution, 50, 141-153.

Pond DW, Gebruk A, Southward EC, Southward AJ, Fallick AE, Bell MV, Sargent JR (2000) Unusual fatty acid composition of storage lipids in the bresilioid shrimp Rimicaris exoculata couples the photic Zone with MAR hydrothermal vent sites. Marine Ecology Progress Series, 198, 171-179.

Plouviez S, Shank TM, Faure B, Daguin-Thiébaut C, Viard F, Lallier FH, Jollivet D (2009) Comparative phylogeography among hydrothermal vent species along the East Pacific Rise reveals vicariant processes and population expansion in the South. Molecular Ecology, 18, 3903-3917.

Posada D, Crandall KA (1998) MODELTEST: testing the model of DNA substitution. Bioinformatics, 14, 817-818. 
Pradillon F, Le Bris N, Shillito B, Young CM, Gaill F (2005) Influence of environmental conditions on early development of the hydrothermal vent polychaete Alvinella pompejana. The Journal of Experimental Biology, 208, 1551-1561

Ray N, Currat M, Excoffier L (2003) Intra-deme molecular diversity in spatially expanding populations. Molecular Biology and Evolution, 20, 76-86.

Raymond M \& Rousset F (1995) Genepop (version 3.2): population genetics software for exact tests and ecumenicism. Journal of Heredity, 86, 248-249.

Sahling H, Bohrmann G, Spiess V, Bialas J, Breitzke M, et al. (2008) Pock-marks in the Northern Congo Fan area, SW Africa: Complex seafloor features shaped by fluid flow. Marine Geology, 249, 206-225.

Samadi S, Bottan L, Macpherson E, De Forges BR, Boisselier M-C (2006) Seamount endemism questioned by the geographic distribution and population genetic structure of marine invertebrates. Marine Biology, 149, 1463- 1475.

Scheltema RS (1986) Long-distance dispersal by planktonic larvae of shoal-water benthic invertebrates among central pacific islands. Bulletin of Marine Science, 39, 241-256, Schneider S, Roessli D, Excoffier L (2000) Arlequin (V2.0): Software for population genetics data analysis. Genetics and biometry laboratory, Department of Anthropology, University of Geneva, Geneva.

Shank TM, Black MB, Halanych KM, Lutz RA, Vrijenhoek RC (1999) Miocene Radiation of Deep-Sea Hydrothermal Vent Shrimp (Caridea: Bresiliidae): Evidence from Mitochondrial Cytochrome Oxidase Subunit I. Molecular Phylogenetics and Evolution, 13, 244-254. Shilling FM, Manahan DT (1994) Energy metabolism and amino acid transport during early development of Antarctic and temperate echinoderms. The Biological Bulletin, 187, 398-407. 
801

802

803

804

805

806

807

808

809

810

811

812

813

814

815

816

817

818

819

820

821

822

823

824

Sibuet M, Vangriesheim A (2009) Deep-sea environment and biodiversity of the West African Equatorial margin. Atlantic, 56, 2156-2168.

Sibuet M, Olu K (1998) Biogeography, biodiversity and fluid dependence of deep-sea coldseep communities at active and passive margins. Deep-Sea Research II, 45, 517-567.

Stewart FJ, Young CR, Cavanaugh CM (2008) Lateral Symbiont Acquisition in a Maternally Transmitted Chemosynthetic Clam Endosymbiosis. Molecular Biology and Evolution, 25, 673- 687.

Storey JD (2002) A direct approach to false discovery rates. Journal of the Royal Statistical Society B, 64, 479-498.

Tajima F (1989) Statistical-method for testing the neutral mutation hypothesis by DNA polymorphism. Genetics, 123, 585-595.

Tajima F (1983) Evolutionary relationships of DNA sequences in finite populations. Genetics, 105, 437-460.

Tajima F (1996) The amount of DNA polymorphism maintained in a finite population when the neutral mutation rate varies among sites. Genetics, 143, 1457-1465.

Teixeira S, Cambon-Bonavita M-A, Serrão ES, Desbruyères D, Arnaud- Haond S (2011a) Recent population expansion and connectivity in the hydrothermal shrimp Rimicaris exoculata along the Mid-Atlantic Ridge. Journal of Biogeography, 38, 564-574.

Teixeira S, Serrão EA, Arnaud-Haond S (2011b) Characterization of 15 polymorphic microsatellite loci in Rimicaris exoculata, and cross-amplification in other hydrothermal-vent shrimp. Conservation Genetic Resources, 4, 84-87.

Teixeira S, Serrão EA, Arnaud-Haond S (2012) Panmixia in a Fragmented and Unstable Environment: The Hydrothermal Shrimp Rimicaris exoculata Disperses Extensively along the Mid-Atlantic Ridge. PLoS ONE, 7, e38521. 
Teixeira S, Olu K, Decker C, Cunha R, Fuchs S, Hourdez S, Serrão E, Arnaud-Haond SData from: High connectivity across the fragmented chemosynthetic ecosystems of the deep Atlantic Equatorial Belt: efficient dispersal mechanisms or questionable endemism? Dryad Digital Repository. doi:10.5061/dryad.cv910

Thaler AD, Zelnio K, Saleu W, Schultz TF, Carlsson J, et al. (2011) The spatial scale of genetic subdivision in populations of Ifremeria nautilei, a hydrothermal vent gastropod from the southwest Pacific. BMC Evolutionary Biology, 11, 372.

Thiele J, Jaeckel S (1931) Muscheln der Deutschen Tiefsee-Expedition. . In: Gustav Fischer J (ed) Wissenschaftliche Ergebnisse der Deutschen Tiefsee-Expedition auf dem Dampfer “Valdivia”, Vol 21 (1), p 159-268.

Thompson JD, Gibson TJ, Plewniak F, Jeanmougin J, Higgins DG (1997) The Clustal X windows interface: Flexible strategies for multiple sequence alignment aided by quality analysis tools. Nucleic Acids Research, 25, 4876-4882.

Tunnicliffe V (1997) Hydrothermal vents: a global ecosystem. In Deep Sea Research in Subduction Zones, Spreading Centers and Backarc Basins (J. Hashimoto and R. Vrijenhoek, eds), p.105-114. JAMSTEC Technical Reports in Deepsea Research/96.

Tunnicliffe V, McArthur AG, McHugh D (1998). Biogeographical perspective of the deepsea hydrothermal vent fauna. Advances in Marine Biology, 34, 353-442.

Turnipseed M, Knick KE, Lipcius RN, Dreyer J, Van Dover CL (2003) Diversity in mussel beds at deep-sea hydrothermal vents and cold seeps. Ecology Letters, 6, 518-523.

Tyler PA, Young CM (1999) Reproduction and dispersal at vents and cold seeps. Journal of the Marine Biological Association of the United Kingdom, 79, 193-208.

Tyler PA, German CR, Ramirez-Llodra E, Van Dover CL (2003) Understanding the biogeography of chemosynthetic ecosystems. Oceanologica Acta, 25, 227-241. 
Van der Heijden K, Petersen JM, Dubilier N, Borowski C (2012) Genetic Connectivity between North and South Mid- Atlantic Ridge Chemosynthetic Bivalves and Their Symbionts. PLoS ONE, 7, e39994.

Van Dover CL, German CR, Speer KG, Parson LM, Vrijenhoek RC (2002) Evolution and biogeography of deep-sea vent and seep invertebrates. Science, 295, 1253-1257.

Vrijenhoek RC (1997) Gene flow and genetic diversity in naturally fragmented metapopulations of deep-sea hydrothermal vent animals. Journal of Heredity, 88, 285-293.

Vrijenhoek RC (2009) Cryptic species, phenotypic plasticity, and complex life histories: Assessing deep-sea faunal diversity with molecular markers. Deep-Sea Research II, doi:10.1016/j.dsr2.2009.05.016

Vrijenhoek RC (2010) Genetic diversity and connectivity of deep-sea hydrothermal vent metapopulations. Molecular Ecology, 19, 4391-4411.

Watanabe H, Fujikura K, Kojima S, Miyazaki J, Fujiwara Y (2010). Japan: Vents and seeps in close proximity. In: S. Kiel (ed.). The Vent and Seep Biota, Topics in Geobiology. 379-401. Weir BS, Cockerham CC (1984) Estimating F-statistics for the analysis of populations structure. Evolution, 38, 1358-1370.

Young CM, Devin M, Jaeckle WB, Ekaratne S (1996) The potential for ontogenetic vertical migration in larvae of deep-sea echinoids. Oceanologica Acta, 19, 263-71.

Young CM, Ekaratne SUK, Cameron JL (1998) Thermal tolerances of embryos and planktotrophic larvae of Archaeopneustes hystrix (Spatangoidea) and Stylocidaris lineate (Cidaroidea), bathyal echinoids from the Bahamian Slope. Journal of Experimental Marine Biology and Ecology, 223, 65-76.

Young CM, He R, Emlet RB, Li Y, Qian H, Arellano SM, Van Gaest A, Bennett KC, Wolf M, Smart TI, Rice ME (2012) Dispersal of Deep-Sea Larvae from the Intra-American Seas: 
873 Simulations of Trajectories using Ocean Models. Integrative and Comparative Biology, 52,

874

875

876

877

878

879

880

881

882

883

884

885

886

887

888

889

890

891

892

893

894

895

896 483-496.

Zelnio KA, Thaler AD, Jones RE, Saleu W, Schultz TF, et al. (2010) Characterization of nine polymorphic microsatellite loci in Chorocaris sp. (Crustacea, Caridea, Alvinocarididae) from deep-sea hydrothermal vents. Conservation Genetic Resources, DOI 10.1007/s12686-0109243-0.

\section{Author contributions}

K.O., C.D., S.H. and S. A. collected the field data. S.T, C.D. and S.F. obtained the genetic data. S.T, C.D. and R.L.C. analysed the data. E.A.S. and S.A. contributed with reagents/ materials/ analysis tools. S.T. and S.A. conceived the ideas. S.T., E.A.S. and S.A. interpreted the data and wrote the article. All authors critically revised the manuscript.

\section{Data Accessability}

DNA sequences: GenBank accessions: Abyssogena southwardae COI haplotypes: JX900981 - JX901014; Alvinocarididae shrimp COI haplotypes: KC840879 - KC840940;

Alvinocarididae shrimp 18S rRNA haplotypes: KC840876 - KC840878

Aligned sequences are available in the Dryad data repository: doi: 10.5061/dryad.cv910

Microsatellite Genotypic Data: A copy of our microsatellite genotypic data, in Genetix format, are available on Dryad, doi: 10.5061/dryad.cv910 
Figure 1. Location of the specimens and populations sampled across the Atlantic Equatorial Belt (AEB). Legend: Triangles- Abyssogena southwardae; circles - species comprised in ESU1 (Alvinocaris muricola /A. markensis); squares - species comprised in the ESU2 (Chorocaris chacei, Alvinocaris methanophila and Rimicaris hybisae). Colour codes: GreenWestern Atlantic; Yellow- Mid-Atlantic Ridge; Orange- Eastern Atlantic.

Figure 2. Phylogenetic relationships of the Abyssogena bivalves based on the maximum likelihood analysis of partial sequence data of the mitochondrial COI gene using the $\mathrm{TrN}+\mathrm{I}$ evolutionary model.

Figure 3. Phylogenetic relationships of Alvinocarididae shrimps sampled in the Atlantic seeps and vents based on the maximum likelihood analysis of partial mitochondrial COI sequence data using the GTR $+\Gamma$ evolutionary model.

Figure 4. Phylogenetic relationships of Alvinocarididae shrimps sampled in the Atlantic seeps and vents based on the maximum likelihood analysis of partial sequences of the $18 \mathrm{~S}$ ribosomal gene using the JC evolutionary model.

Figure 5. Haplotype networks of the mtDNA haplotypes obtained for Abyssogena southwardae bivalves and for both clades (ESU1 and 2) recovered for the Alvinocarididae shrimp of the AEB. Each circle represents a different haplotype, with the size of each circle proportional to the number of individuals displaying that particular haplotype. The colours used represent the locations where the haplotypes were found and within pie charts, the segment size is proportional to the relative frequency of a haplotype in each population where it is present. Mutation steps are represented only when higher than 1. 
922 Table 1. GenBank accession numbers, specimen collection sites and depth of species used for

923 phylogenetic analyses.

\begin{tabular}{|c|c|c|c|c|c|c|c|}
\hline Specimen & $\begin{array}{l}\text { Nomenclature } \\
\text { according to } \\
\text { Audzijonyte et } \\
\text { al. } 2012\end{array}$ & Accession $n^{\circ}$ & Sample site & Area & Habitat & $\begin{array}{l}\text { Depth } \\
\text { (m) }\end{array}$ & $\begin{array}{l}\text { Study; } \\
\text { sample size }\end{array}$ \\
\hline \multicolumn{8}{|l|}{ Bivalves } \\
\hline $\begin{array}{l}\text { Abyssogena } \\
\text { southwardae }\end{array}$ & & $\begin{array}{l}\text { JX900981; } \\
\text { JX901014 }\end{array}$ & $\begin{array}{l}\text { WormHole } \\
\text { pockmark }\end{array}$ & $\begin{array}{l}\text { East } \\
\text { Atlantic }\end{array}$ & Seep & 3089 & $\begin{array}{l}\text { This study; } \\
2\end{array}$ \\
\hline $\begin{array}{l}\text { Abyssogena } \\
\text { southwardae }\end{array}$ & & $\begin{array}{l}\text { JX900982- } \\
\text { JX901013 }\end{array}$ & $\begin{array}{l}\text { Lobes of the } \\
\text { Congo deep- } \\
\text { sea fan }\end{array}$ & $\begin{array}{l}\text { East } \\
\text { Atlantic }\end{array}$ & $\begin{array}{l}\text { Presumably } \\
\text { Seep }\end{array}$ & 4946 & $\begin{array}{l}\text { This study; } \\
32\end{array}$ \\
\hline $\begin{array}{l}\text { Calyptogena } \\
\text { kaikoi }\end{array}$ & $\begin{array}{l}\text { Abyssogena } \\
\text { kaikoi }\end{array}$ & AB110763 & $\begin{array}{l}\text { Off Muroto } \\
\text { Point, } \\
\text { Nankai } \\
\text { Trough }\end{array}$ & $\begin{array}{l}\text { Western } \\
\text { Pacific }\end{array}$ & Seep & 4800 & $\begin{array}{l}\text { Kojima et } \\
\text { al. } 2004\end{array}$ \\
\hline $\begin{array}{l}\text { Vesicomyidae } \\
\text { sp. ' 'Ryukyu } \\
\text { Trench' }\end{array}$ & $\begin{array}{l}\text { Abyssogena sp. } \\
\text { Ryuku }\end{array}$ & AB110775 & $\begin{array}{l}\text { Ryukyu } \\
\text { Trench }\end{array}$ & $\begin{array}{l}\text { Western } \\
\text { Pacific }\end{array}$ & Seep & 5900 & $\begin{array}{l}\text { Kojima et } \\
\text { al. } 2004\end{array}$ \\
\hline $\begin{array}{l}\text { Calyptogena } \\
\text { sp. 6K1234- } \\
1 / 2\end{array}$ & $\begin{array}{l}\text { Abyssogena } \\
\text { mariana }\end{array}$ & AB629938/ 39 & $\begin{array}{l}\text { Shinkai } \\
\text { Seep Field }\end{array}$ & $\begin{array}{l}\text { Western } \\
\text { Pacific }\end{array}$ & Vents & 5550 & $\begin{array}{l}\text { Ohara et al. } \\
\text { 2012; } \\
\text { Okutani } \\
\text { etal. } 2013\end{array}$ \\
\hline $\begin{array}{l}\text { Calyptogena } \\
\text { phaseoliformis }\end{array}$ & $\begin{array}{l}\text { Abyssogena } \\
\text { phaseoliformis }\end{array}$ & AB479088 & $\begin{array}{l}\text { Kurile } \\
\text { Trench }\end{array}$ & $\begin{array}{l}\text { Western } \\
\text { Pacific }\end{array}$ & Seep & 4819 & $\begin{array}{l}\text { Okutani et } \\
\text { al. } 2009\end{array}$ \\
\hline $\begin{array}{l}\text { Calyptogena } \\
\text { sp. }\end{array}$ & $\begin{array}{l}\text { Abyssogena } \\
\text { southwardae }\end{array}$ & $\begin{array}{l}\text { AF008279; } \\
\text { JX196983 }\end{array}$ & $\begin{array}{l}\text { Barbados } \\
\text { Accretionary } \\
\text { Prism }\end{array}$ & $\begin{array}{l}\text { Western } \\
\text { Atlantic }\end{array}$ & Seep & 5000 & $\begin{array}{l}\text { Peek et al. } \\
\text { 1997; } \\
\text { Audzijonyte } \\
\text { et al. } 2012\end{array}$ \\
\hline
\end{tabular}




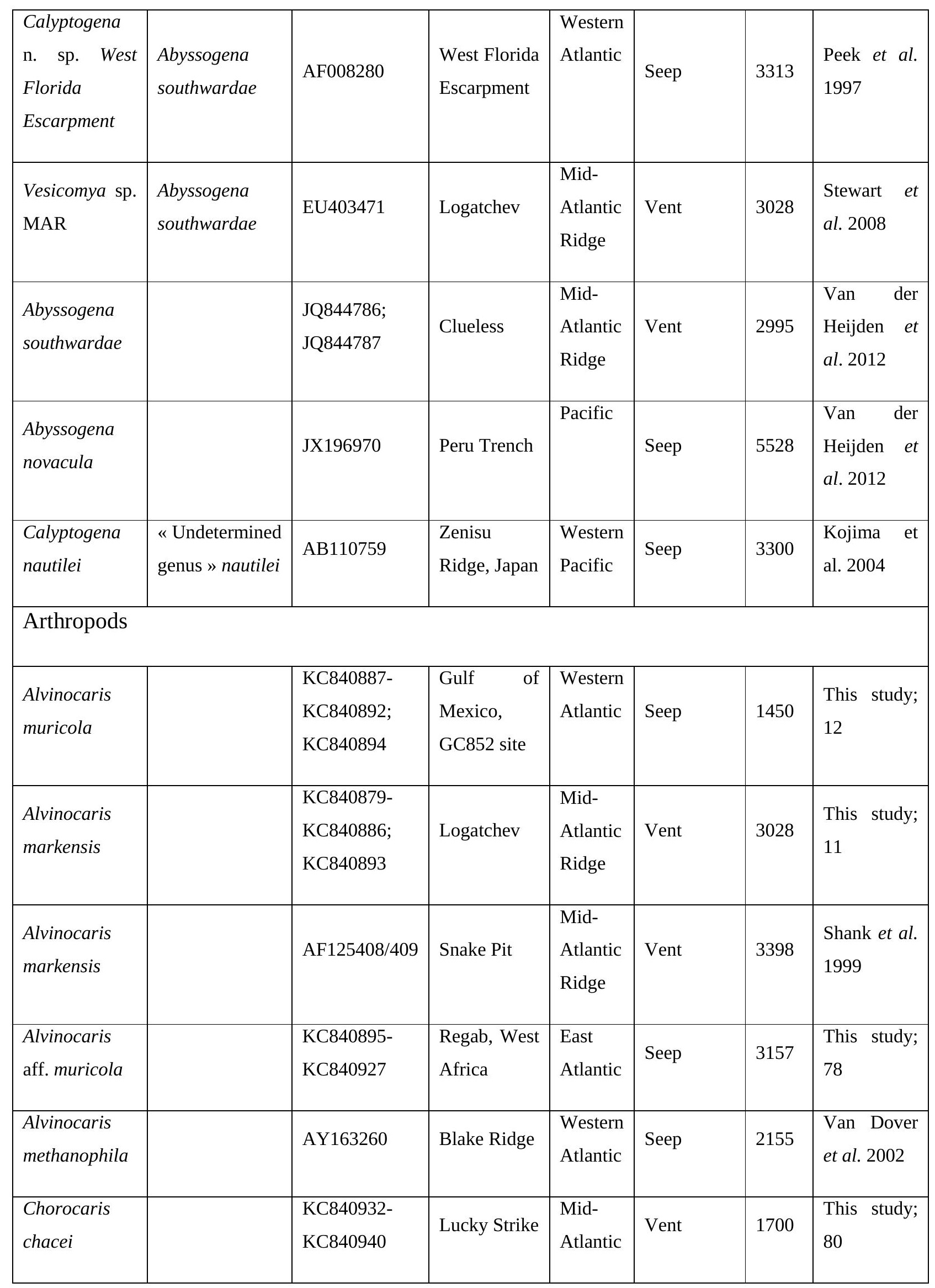




\begin{tabular}{|c|c|c|c|c|c|c|}
\hline & & & Ridge & & & \\
\hline $\begin{array}{l}\text { Chorocaris } \\
\text { chacei }\end{array}$ & $\begin{array}{l}\text { КС840928- } \\
\text { КС840931 }\end{array}$ & Logatchev & $\begin{array}{l}\text { Mid- } \\
\text { Atlantic } \\
\text { Ridge }\end{array}$ & Vent & 3028 & $\begin{array}{l}\text { This study; } \\
16\end{array}$ \\
\hline $\begin{array}{l}\text { Rimicaris } \\
\text { hybisae }\end{array}$ & JN850607 & $\begin{array}{l}\text { Mid- } \\
\text { Cayman } \\
\text { Ridge }\end{array}$ & $\begin{array}{l}\text { Western } \\
\text { Atlantic }\end{array}$ & Vent & 4960 & $\begin{array}{l}\text { Nye et al. } \\
2012\end{array}$ \\
\hline
\end{tabular}

926 Table 2. Details of primers and PCR conditions used for the different molecular markers

927 amplified.

\begin{tabular}{|c|c|c|c|}
\hline & $\begin{array}{l}\text { Cytochrome } \\
\text { Oxydase subunit I } \\
\text { (Folmer et al., 1994) }\end{array}$ & $\begin{array}{l}\text { 18S rRNA (López- } \\
\text { García et al., 2003) }\end{array}$ & $\begin{array}{l}\text { Microsatellites } \\
\text { (Teixeira et al., } \\
\text { 2011b ; Zelnio et al. } \\
\text { 2010) }\end{array}$ \\
\hline Primer names & $\begin{array}{l}\text { LCOI1490; } \\
\text { HCOI2198 }\end{array}$ & $\begin{array}{l}\text { 18S-82F ; 18S- } \\
\text { 1498R }\end{array}$ & $\begin{array}{l}\operatorname{Rim} 11 ; 12 ; 26 ; \\
30 ; 32 ; 42 ; \mathrm{CHO} \\
83 ; 91\end{array}$ \\
\hline DNA (ng) & 50 & 50 & 10 \\
\hline $\mathrm{MgCl}_{2}(\mathrm{mM})$ & 2.5 & 3 & 3 \\
\hline dNTP (mM) & 0.8 & 0.8 & 0.8 \\
\hline $\operatorname{Taq}(\mathrm{U} / \mu \mathrm{l})$ & 0.4 & 0.4 & 0.5 \\
\hline
\end{tabular}




\begin{tabular}{|l|l|l|l|}
\hline Final volume $(\mu \mathrm{l})$ & 50 & 20 & 10 \\
\hline Annealing & 52 & 56 & (Teixeira et al., \\
temperature $\left({ }^{\circ} \mathrm{C}\right)$ & & & $2011 \mathrm{~b}$; Zelnio et al. \\
& & & \\
\hline
\end{tabular}

Table 3. Genetic diversity indices based on COI partial sequences (517 bp) of the deep-sea shrimp Alvinocaris sampled across the Atlantic equatorial belt calculated for each sampled site. (n) sample size; $(k)$ number of polymorphic sites; $(N \mathrm{~h})$ number of haplotypes; $(N \mathrm{ph})$ number of private haplotypes, i.e. the number of haplotypes exclusive of a population; $(h)$ haplotype diversity; $\left(\pi_{1}\right)$ mean number of pairwise differences; $\left(\pi_{2}\right)$ nucleotide diversity. Neutrality and population expansion tests: $D=$ Tajima's D-test; $F_{S}=$ Fu's $F_{S}$ test. All values obtained for the neutrality tests were significant at the $5 \%$ level.

\begin{tabular}{|c|c|c|c|c|c|c|c|c|c|}
\hline Site & $n$ & $k$ & Nh & $N p h$ & $h$ & $\pi_{1}$ & $\pi_{2}$ & $D$ & $F_{\mathrm{S}}$ \\
\hline Gulf of Mexico & 12 & 14 & 9 & 5 & $0.91 \pm 0.08$ & 2.47 & 0.0047 & -1.99 & -4.83 \\
\hline Logatchev & 11 & 11 & 9 & 7 & $0.96 \pm 0.05$ & 2.87 & 0.0050 & -1.01 & -4.83 \\
\hline West Africa & 78 & 43 & 37 & 33 & $0.80 \pm 0.05$ & 1.95 & 0.0037 & -2.51 & -27.45 \\
\hline
\end{tabular}

Table 4. Descriptive statistics based on 9 microsatellite loci for Alvinocaris shrimp from ESU1 from all sampled locations. Number of individuals sampled (n), mean number of alleles across loci (A), $\mathrm{A}_{\text {rich }}$ standardized allelic richness for a minimum of 12 individuals, observed 
$941\left(H_{\mathrm{O}}\right)$ and expected $\left(H_{\mathrm{E}}\right)$ heterozygosities and heterozygote deficiency $\left(F_{\mathrm{IS}}\right)$. Bold numbers 942 indicate significant values $\left({ }^{* * *} \mathrm{p}<0.001\right)$ after q-value correction.

\begin{tabular}{|l|l|l|l|l|l|l|}
\hline Site & $\mathrm{n}$ & $A$ & $\mathrm{~A}_{\text {rich }}$ & $H_{\mathrm{E}}$ & $H_{\mathrm{O}}$ & $F_{\mathrm{IS}}$ \\
\hline Gulf of Mexico & 14 & 5.8 & 5.47 & 0.64 & 0.52 & $\mathbf{0 . 1 8}^{* * * *}$ \\
\hline Logatchev & 17 & 5.4 & 4.67 & 0.65 & 0.62 & 0.04 \\
\hline West Africa & 67 & 8.8 & 4.89 & 0.59 & 0.53 & $\mathbf{0 . 0 9}^{* * *}$ \\
\hline
\end{tabular}

943

Table 5. Pairwise $F_{\mathrm{ST}}$ values based on haplotype (COI) and allele frequencies (9 945 microsatellite loci) for the ESU1 Alvinocaris species sampled across the Atlantic equatorial 946 belt. Significant levels are indicated $\left({ }^{*} \mathrm{p}<0.05 ;{ }^{* * *} \mathrm{p}<0.001\right)$.

\begin{tabular}{|c|l|l|l|l|}
\hline \multirow{2}{*}{ Sites } & \multicolumn{2}{|c|}{ COI marker } & \multicolumn{2}{c|}{ Microsatellite markers } \\
& Mexico & & Gulf of Mexico & Logatchev \\
& & & & \\
\hline Gulf of Mexico & & & & \\
\hline Logatchev & -0.005 & & 0.022 & \\
\hline West Africa & $0.047^{*}$ & -0.007 & $0.041^{* * *}$ & $0.078^{* * *}$ \\
\hline
\end{tabular}

947 
Table 6. Estimation of $M$ and $\Theta$ generated in MIGRATE analysis of mtDNA sequences (COI) of the ESU1 Alvinocaris species sampled across the AEB. Values in parentheses denote the 95\% profile likelihoods for each estimate; all values were obtained in one independent run.

\begin{tabular}{|l|l|l|l|}
\hline Sites & Gulf of Mexico $\Theta=0.09$ & Logatchev $\Theta=$ & West Africa $\Theta=0.034$ \\
& & 0.0154 & \\
\hline Gulf of Mexico & - & $4.1 \times 10^{-6}\left(3.1 \times 10^{-6}-\right.$ & $1.4 \times 10^{-5}\left(1.1 \times 10^{-5}-0.04\right)$ \\
& & $0.01)$ & \\
\hline Logatchev & $2 \times 10^{3}\left(1.1 \times 10^{3}-3.5 \times 10^{3}\right)$ & - & $3.1 \times 10^{3}\left(2.4 \times 10^{3}-4.8 \times 10^{3}\right)$ \\
\hline West Africa & $3.7 \times 10^{-5}\left(2.8 \times 10^{-5}-\right.$ & $4.1 \times 10^{-6}\left(3.1 \times 10^{-6}-\right.$ & - \\
& $0.09)$ & $0.01)$ & \\
\hline
\end{tabular}

952

Donor populations represent the lines, recipient populations represent the columns

953

954

955

956

957

958

959 


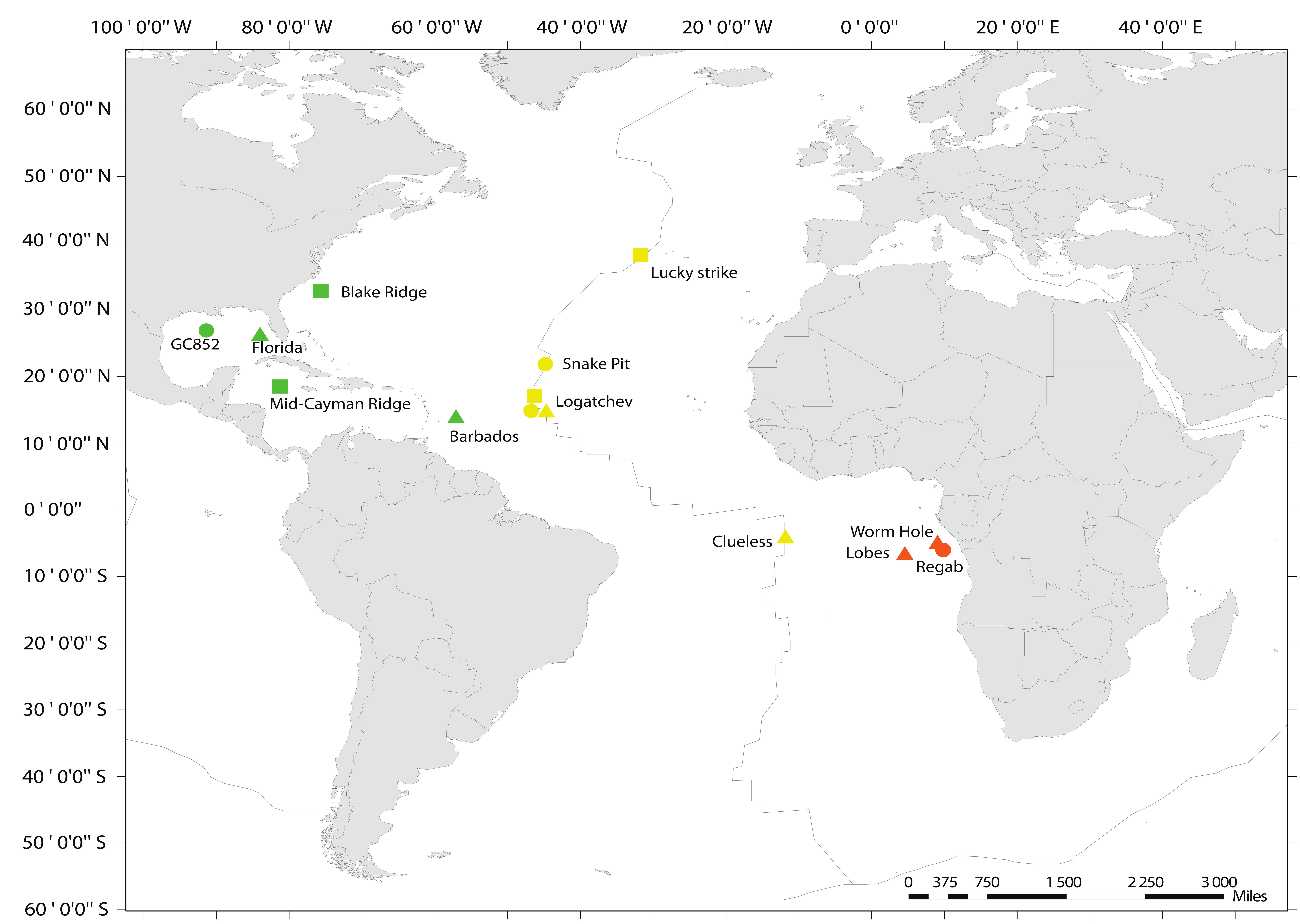

Alvinocaris muricola and A. markensis

- Chorocaris chacei, Alvinocaris methanophila, Rimicaris hybisae

$\Delta \Delta$ Abyssogena southwardae 
West Florida Escarpment Seep

\section{Abyssogena novacula JX196970}

Abyssogena sp Ryukyu. AB110775

Abyssogena phaseoliformis AB479088

93 Abyssogena mariana AB629938

100 Abyssogena mariana AB629939

Abyssogena kaikoi AB110763

Abyssogena southwardae 486V6 Abyssogena southwardae 492V35

Abyssogena southwardae 492V29

Abyssogena southwardae 492V6

Abyssogena southwardae 431V1

Abyssogena southwardae 492V4

Abyssogena southwardae 492V18

Abyssogena southwardae 491V1B

Abyssogena southwardae 491V42

Abyssogena southwardae 492V7

Abyssogena southwardae $492 \mathrm{~V} 8$

Abyssogena southwardae 492V15 


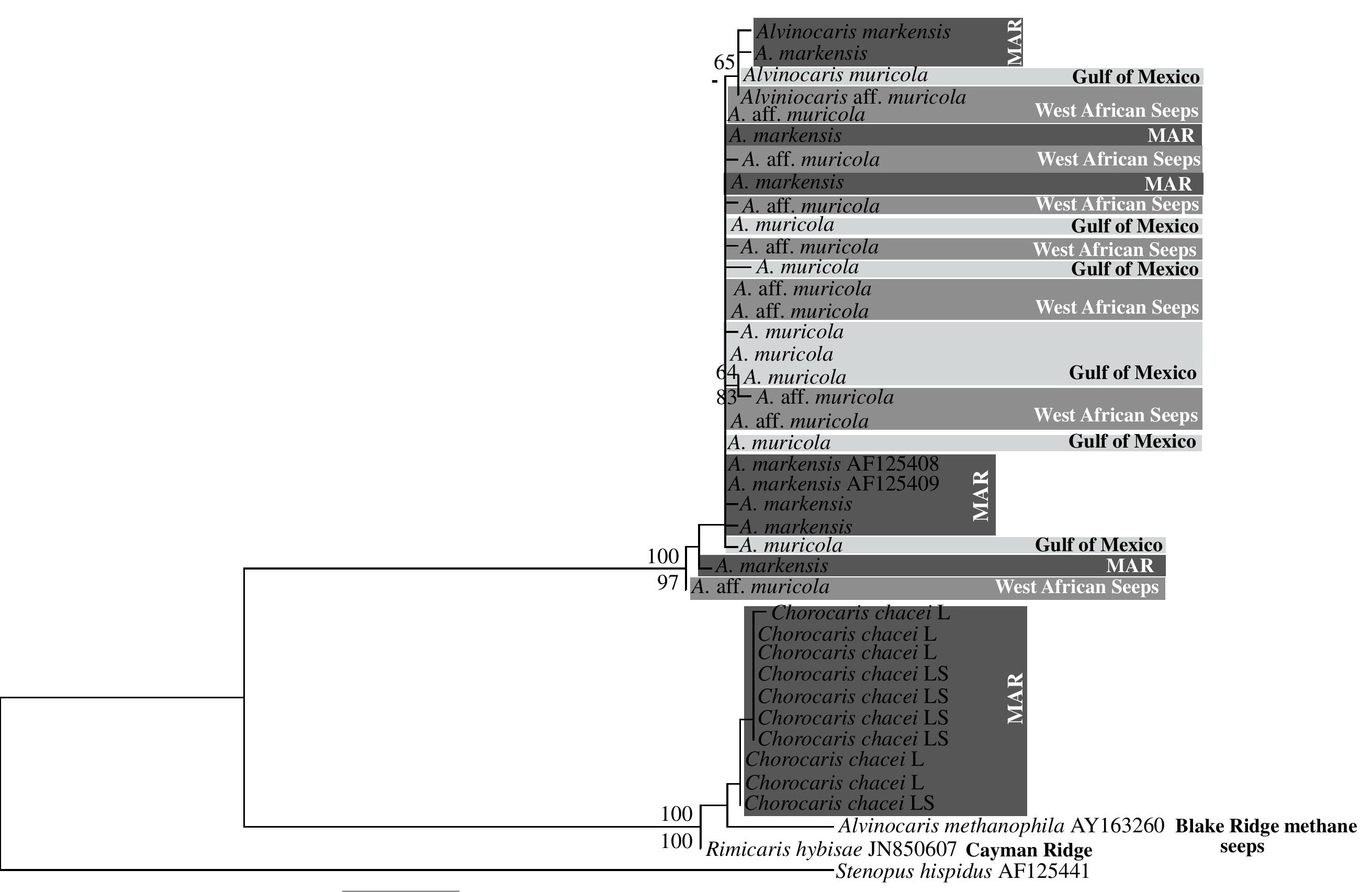

0.02 substitutions/ site 


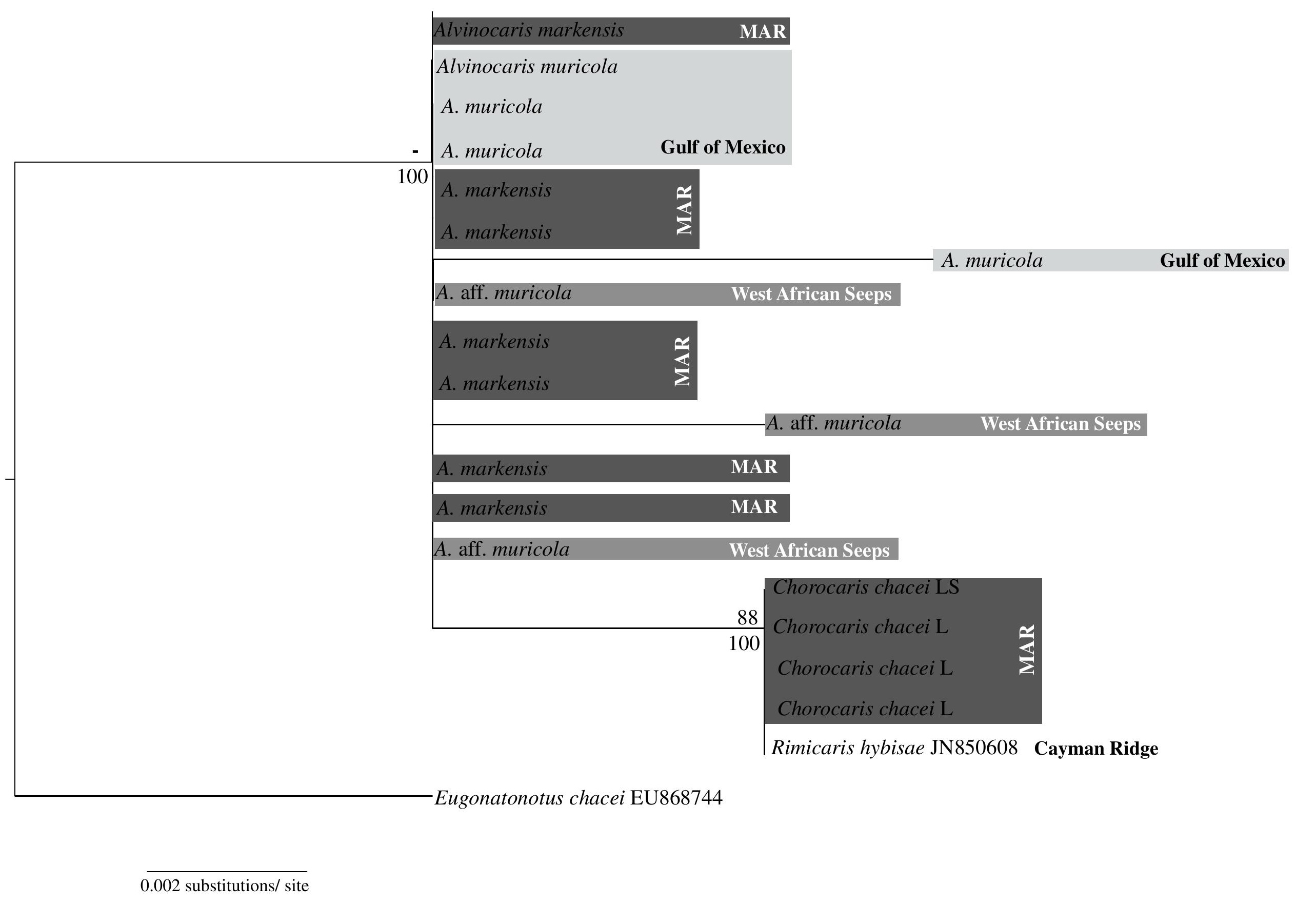




\section{Abyssogena southwardae}

$\square$ Barbados Accretionary Prism

- Florida Escarpment

$\square$ MAR

$\square$ South MAR

West Africa Seeps

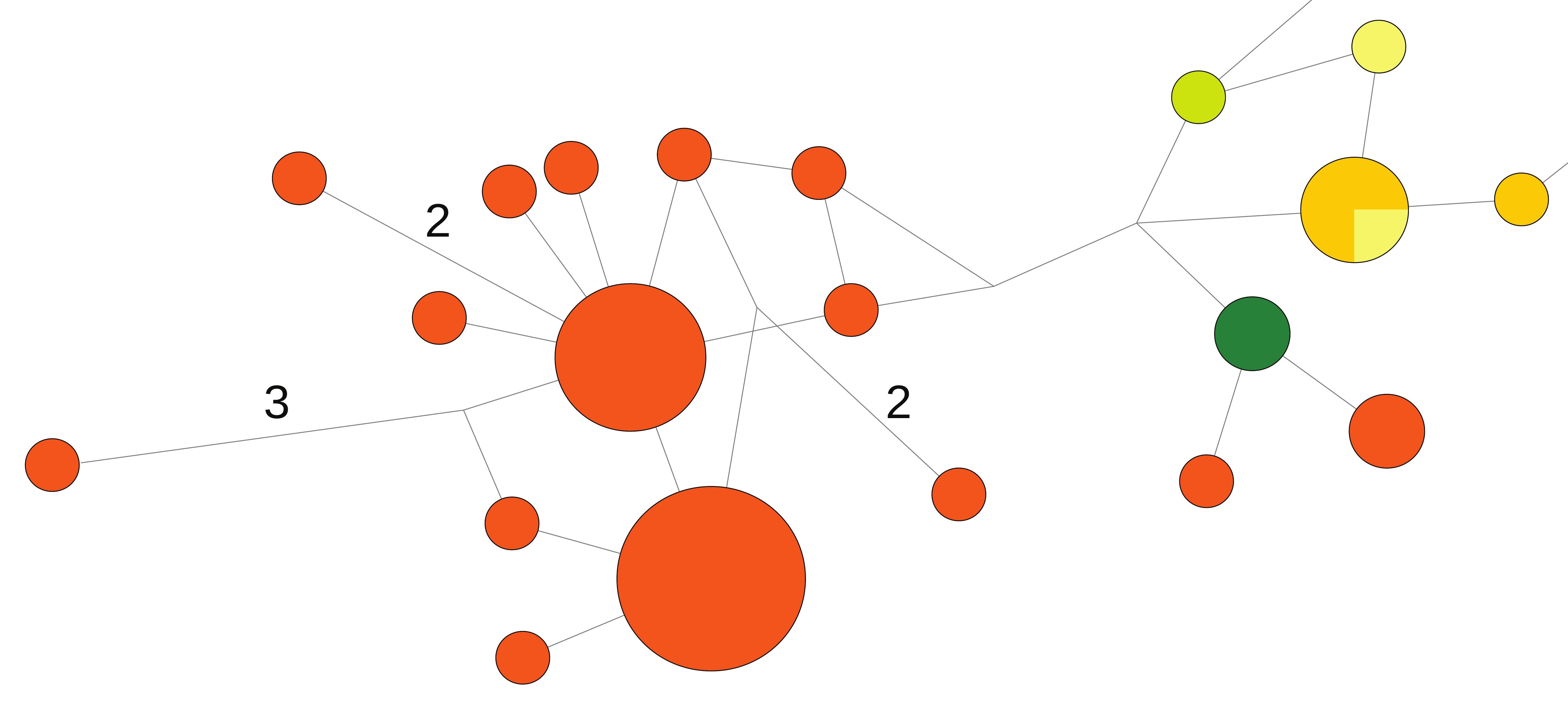

\section{Alvinocarididae ESU1}

$\square$ Alvinocaris markensis MAR(Logatchev)

Alvinocaris muricola Gulf of Mexico

$\square$ Alvinocaris aff. muricola West Africa

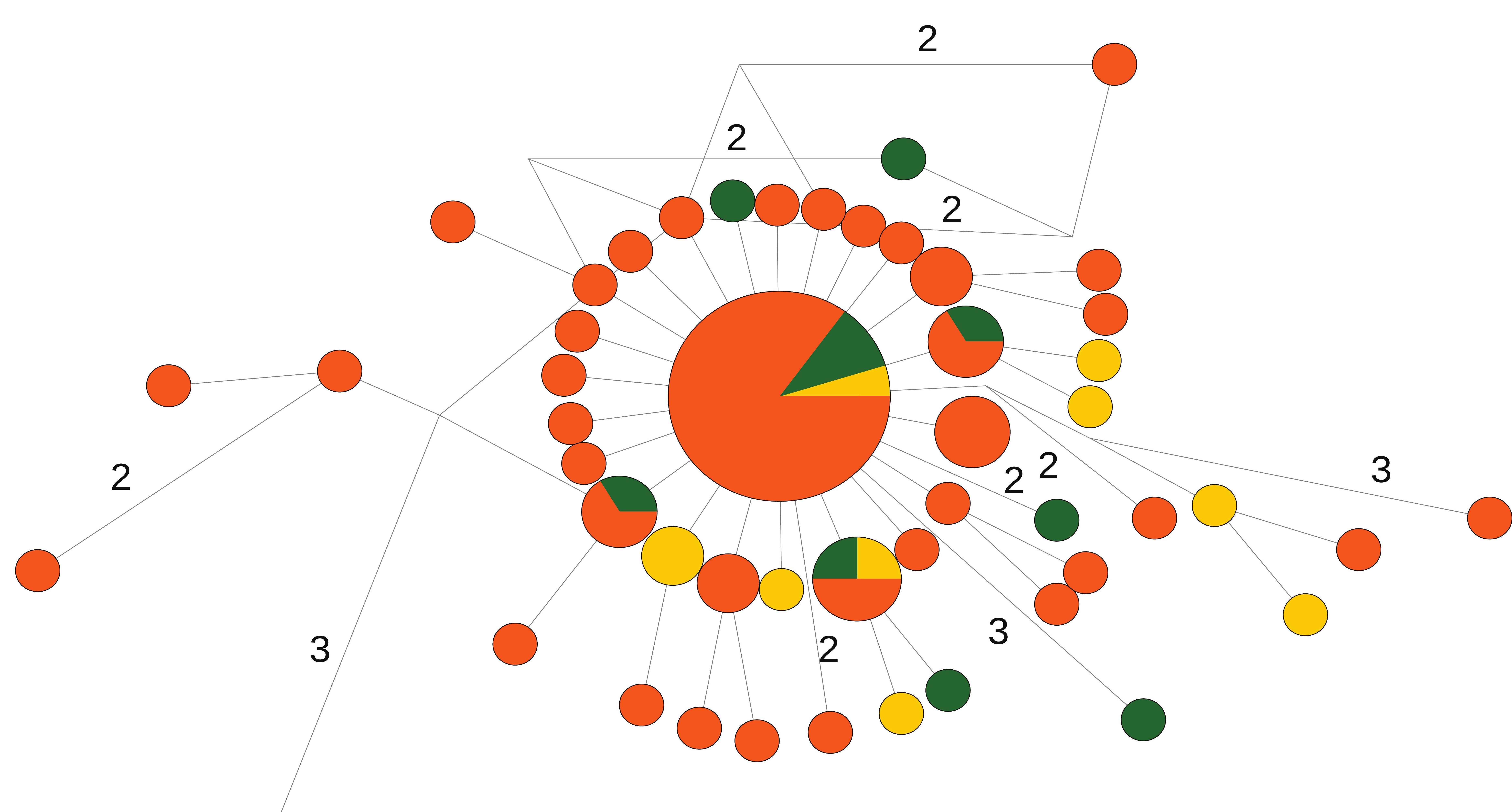

\section{Alvinocarididae ESU2}

$\square$ Chorocaris chacei MAR (Logatchev)

$\square$ Chorocaris chacei MAR (Lucky Strike)

- Alvinocaris methanophila Blake Ridge seep

$\square$ Rimicaris hybisae Cayman Ridge

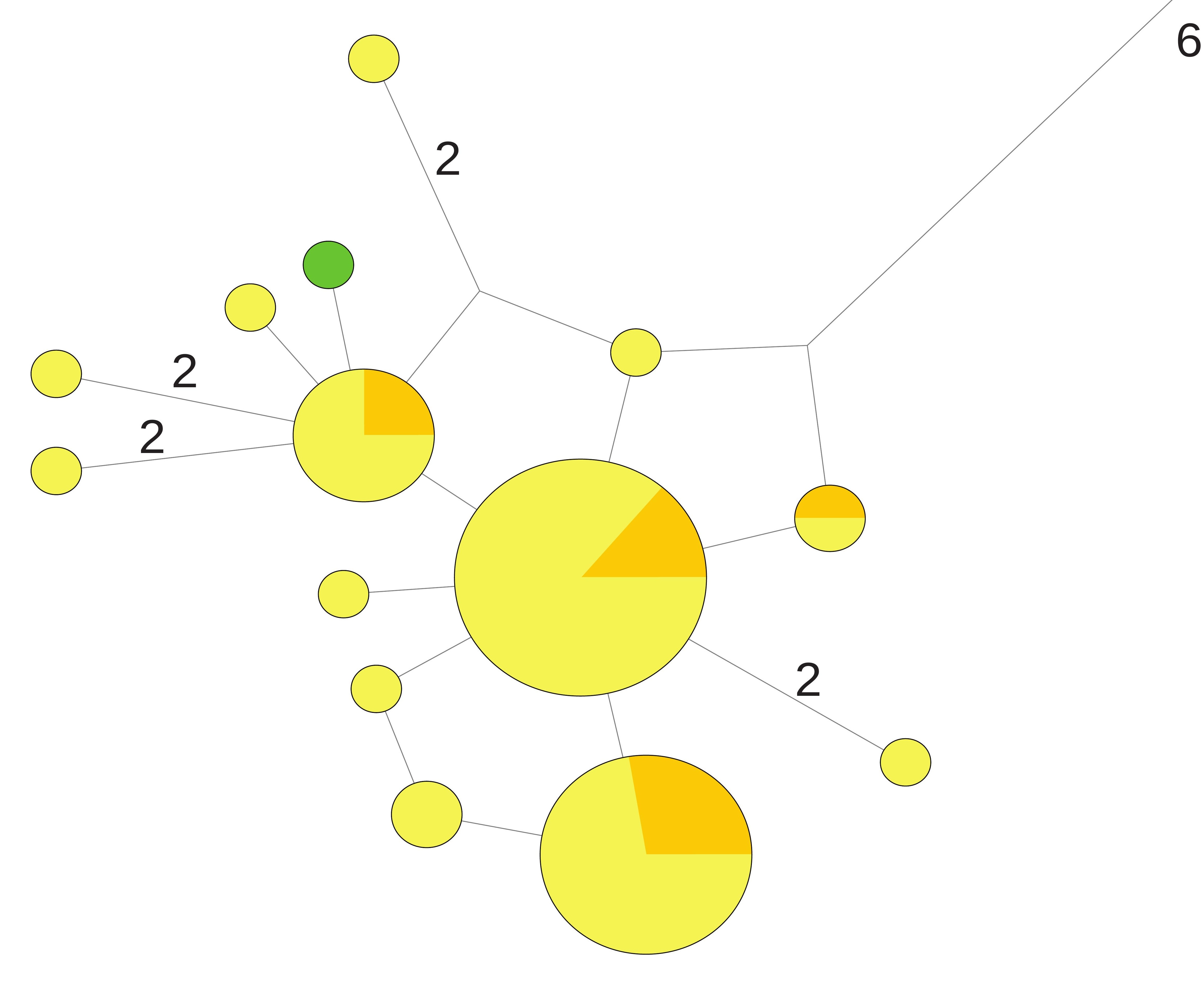

